\title{
LADISLAV NOVOMESKÝ A SLOVENSKÁ KULTURNÍ OBEC V PROPAGANDISTICKÉ KAMPANI PROTI TZV. BURŽOAZNÍMU NACIONALISMU NA JAŘE 1951
}

\author{
ZDENĚK D O S K O Č I L
}

\begin{abstract}
DOSKOČIL, Zdeněk. Ladislav Novomeský and the Slovak cultural community in the propagandist campaign against the so-called bourgeois nationalists in spring 1951. Historický časopis, 2018, 66, 3, pp. 457-492, Bratislava.

In spring 1950 the poet and commissioner for education Ladislav Novomeský was tactically accused of so-called Slovak bourgeois nationalism. Under the influence of Soviet advisers in the State Security Service, the accusation of ideological deviation was reclassified as a criminal offence and Novomeský ended up in prison together with other functionaries in February 1951. After their arrest, a propagandist campaign was unleashed against so-called bourgeois nationalism. The leadership of the Communist Party of Slovakia combined it with purges of the Slovak intelligentsia. Novomeský became one of the victims. Communist intellectuals were included on the initiative of politicians and party apparatchiks. Their speeches and articles sharply condemned Novomeský's poetry, his literary views, expert work and activities in the fields of education and culture. For a number of years, the campaign damaged Czech - Slovak relations and the development of the Slovak political and cultural spheres. It marked Novomeský's life, since his conviction became the basis for the charges against him in the trial of so-called Slovak bourgeois nationalists in 1954. Key words: Ladislav Novomeský. Davisté. Communist Party of Slovakia. Propaganda. Bourgeois nationalism. Repression. Political trials.
\end{abstract}

\section{DOI: https://doi.org/10.31577/histcaso.2018.66.3.4}

Život básníka, žurnalisty a předválečného člena KSČ Ladislava Novomeského (1904-1976) byl již od let dospívání trvale spjat s politikou. Do jejích vyšších pater však Novomeský pronikl až na sklonku druhé světové války, kdy se jako člen V. ilegálního vedení Komunistické strany Slovenska (KSS) a člen odbojové Slovenské národní rady (SNR) významně podílel na organizaci Slovenského národního povstání (SNP) i prosazení nového státoprávního uspořádání česko-slovenských vztahů, které odmítlo etnický čechoslovakismus a obnovenou Československou republiku ustavilo jako stát dvou rovnoprávných národů, Čechů 
a Slováků. ${ }^{1}$ V poválečných letech vykonával četné stranické a státní funkce. Jako pověřenec školství a osvěty přispěl na Slovensku k otevření řady nových škol a inspiroval vznik četných kulturních institucí. Zároveň ale byl disciplinovaným členem komunistické strany, který mezi roky 1945-1948 respektoval všechny posuny její politické strategie a taktiky. Podílel se na jejím úsilí o dosažení mocenského monopolu a nezůstal ani stranou událostí února 1948.

Nicméně i na vedoucích postech si Novomeský dokázal uchovat habitus nekonformního levicového intelektuála, přejícího nedogmatické kulturní politice a tolerantního vůči prŕśslušníkům nekomunistické inteligence. Navíc své účinkování ve vrcholné politice považoval za dočasnou záležitost a osobní obět', které si vynutila válka a turbulentní politický vývoj po osvobození. Vícekrát po roce 1945 neúspěšně žádal vedení KSS, aby byl svých exponovaných funkcí zproštěn. ${ }^{2}$ Jeho politické angažmá tak ukončila teprve kampaň proti tzv. slovenskému buržoaznímu nacionalismu na jaře 1950, kdy byl v houstnoucí atmosfére hledání „nepřátel uvnitř strany“ společně s Vladimírem Clementisem, Gustávem Husákem a Karolem Šmidkem donucen k ponižující sebekritice a odchodu z politického života. Vykonstruované obvinění z nacionální úchylky mělo své kořeny ve Stalinově konfliktu s jugoslávským vůdcem Josipem Brozem Titem z roku 1948. Souviselo s úsilím sovětského vůdce o odstranění bývalých předáků domácí komunistické rezistence v jednotlivých lidově demokratických zemích, kteří byli podezříváni z možné ochoty následovat jugoslávský vzor. Po vzoru mnohonárodnostního Sovětského svazu, kde byli již ve třicátých letech z tzv. buržoazního nacionalismu protisovětského (protiruského) zaměření očerňováni příslušníci menších etnik (Ukrajinci, Bělorusové, Gruzínci), bylo v Československu, jako státu dvou národů, tažení proti nacionální úchylce zaměřeno do slovenského prostředí. Tímto tahem se vedení KSČ (a s ním spjatí slovenští funkcionáři působící v Praze) pokusilo odvést pozornost bezpečnostních orgánů směrem, jenž by ho prŕliš neohrožoval. Zároveň nalezlo způsob, který definitivně umožnil vyřešit slovenskou otázku v centralistickém duchu a současně dovedl k finálnímu rozuzlení mocenský konflikt mezi centralistickým (Viliam Široký,

1 Nejnovější syntetický pohled na komunistickou rezistenci přináší SYRNÝ, Marek. Slovenskí komunisti v rokoch 1939-1944: Náčrt dejín Komunistickej strany Slovenska v odboji a v Povstaní. Banská Bystrica: Belianum, 2013. ISBN 9788055706733.

2 Nejvíce informací o Novomeského politických a veřejných aktivitách v letech 1945-1950, zasazených do dobového slovenského kulturně-politického kontextu, přináší DRUG, Štefan (ed.). Umenie politiky, politika umenia: Z listov Laca Novomeského, sv. I-II. Bratislava: Tatran, 1988 - 1989. ISBN 8022201596. S přihlédnutím k lidskému rozměru básníkovy osobnosti sleduje autor studie tuto problematiku v hutném přehledu ve stati: DOSKOČIL, Zdeněk. Jak se Ladislav Novomeský stal slovenským buržoazním nacionalistou. In DRUG, Štefan. Väzeň vlastných súdruhov: Z väzeňských rokov básnika Novomeského. Košice; Fintice: FACE, 2015, s. 68-76. 
Július Ďuriš, Štefan Bašt’ovanský, Karol Bacílek aj.) a národně orientovaným, tzv. povstaleckým (Clementis, Husák, Šmidke, Novomeský ad.) kř́ílem KSS, vlekoucí se již od osvobození. Za tzv. československého Rajka byl na přelomu let 1949-1950 vyhlédnut Vladimír Clementis. Na něj a funkcionáře s ním úzce spjaté, k nimž Novomeský patřil, StB již od podzimu 1948 shromažd’ovala kompromitující materiál. ${ }^{3}$

Na IX. sjezdu KSS v květnu 1950 odsoudil Viliam Široký tzv. buržoazní nacionalismus jen $\mathrm{v}$ ideologické rovině. Napadení funkcionáři byli potrestáni pouze stranicky - odvoláním z funkcí. ${ }^{4}$ Nikdo z nich nebyl vyloučen z KSČ, natož zatčen nebo postaven před soud. Výsledky sjezdových rokování vyvolaly v Moskvě značnou nespokojenost, nebot’ Širokým vyslovená kritika nebyla primárně zaměřena protisovětsky a projugoslávsky, nýbrž protičesky. Koncepce připravovaného spiknutí tak získala pouze lokální charakter a nemohla se svým významem ani zdaleka rovnat soudnímu přelíčení s László Rajkem v Mad’arsku. Tento fakt prriměl Josifa Visarionoviče Stalina v létě 1950 k výměně sovětských poradců v Československu. Jejich nová garnitura byla pověřena vyrobit politický proces se skupinou vedoucích funkcionářủ, který by získal celostátní rozměr. Na přelomu let 1950-1951 tak byla v součinnosti s vyšetřovateli StB vytvořena koncepce založená na existenci dvou provázaných skupin. Do čela jedné

3 V souvislosti s Novomeským se analýze politicko-ideologických aspektů a mezinárodních souvislostí tzv. slovenského buržoazního nacionalismu autor blíže věnoval v následujících studiích: DOSKOČIL, Zdeněk. Básník Ladislav Novomeský v hledáčku Státní bezpečnosti (1948-1950). In Východočeské listy historické, 2017, č. 37, s. 37-63. ISSN 1211-8184; DOSKOČIL, Zdeněk. Obvinění Ladislava Novomeského z tzv. slovenského buržoazního nacionalismu a jeho sebekritika na jaře 1950. In Moderni dějiny, 2017, roč. 25, č. 2, s. 189-238. ISSN 1210-6860. V obecnější rovině se historiografie otázkou tzv. buržoazního nacionalismu již obsáhle zabývala. Z nejdůležitějších prací srov. GĄSIOR, Grzegorz. Stalinowska Stowacja: Proces ,burżuazyjnych nacjonalistów“ w 1954 roku. Warszawa: Wydawnictwo Trio, 2006. ISBN 8374360453; dále RYCHLÍK, Jan. Češi a Slováci ve 20. století : Česko-slovenské vztahy 1945-1992. Bratislava: Academic Electronic Press, 1998, s. 146-169. ISBN 8088880114; RYCHLÍK, Jan. Proces proti tzv. slovenským buržoazním nacionalistům. In Česko-slovenská historická ročenka 2005. Brno: Masarykova univerzita v Brně, 2005, s. 181-194. ISBN 8021038950; UHER, Ján. Zo zákulisia rehabilitácií: Tajomstvo Kolderovej komisie. Bratislava: Kalligram, 2001. ISBN 807149461; BARNOVSKÝ, Michal. Proces s tzv. slovenskými buržoáznymi nacionalistami. In PERNES, Jiří - FOITZIK, Jan (eds.). Politické procesy v Československu po roce 1945 a „připad Slánský“. Brno: Prius, 2005, s. 158-170. ISBN 8072850539; ČERNÁK, Tomáš. Sláva a pád Gustáva Husáka: Vybrané kapitoly z rokov 1948 1951. Bratislava: Filozofická fakulta Univerzity Komenského, 2009 (rigorózní práce), s. 34-87; MACHÁČEK, Michal. Gustáv Husák. Praha: Vyšehrad, 2017, s. 239-267.

4 Po stranickém sjezdu byl básník odsunut na druhořadý post předsedy Správy Slovenské akademie věd a umění. Více k tomu DOSKOČIL, Zdeněk. Ladislav Novomeský v čele Slovenské akademie věd a umění (1950-1951). In Studia Historica Nitriensia, 2017, roč. 21, č. 2 , s. 348-365. ISSN 1338-7219. 
z nich poradci postavili bývalého krajského tajemníka KSČ v Brně Otto Šlinga a zástupkyni generálního tajemníka ÚV KSČ Marii Švermovou. Druhou větev představovali tzv. slovenští buržoazní nacionalisté v čele s Clementisem. Jejich kauzy byly navzájem propojeny. Tmelem obou frakcí měl být tzv. buržoazní nacionalismus, který se ovšem $\mathrm{v}$ jednotlivých případech interpretoval rozdílně. Švermová se Šlingem propadli ideologii „národního komunismu“, tedy preferovali potřeby Československa před zájmy Sovětského svazu. Usilovali nejprve o převrat ve vedení strany, kterým by odstranili Rudolfa Slánského, Antonína Zápotockého i Klementa Gottwalda. Následně chtěli obnovit kapitalismus a převést republiku po vzoru Jugoslávie do tábora imperialistů. K celostátnímu spiknutí byla připojena jeho odnož v podobě tzv. slovenských buržoazních nacionalistů, která se vedle společných cílů navíc snažila rozvrátit jednotu republiky a obnovit samostatný slovenský stát. Novomeský se tak paradoxně dostal do vězení teprve v situaci, kdy význam tzv. slovenských buržoazních nacionalistů v připravovaném monstrprocesu v porovnání s léty 1949-1950 poklesl. Z úhlavních nepřátel, postavených na roveň Rajkovi, se stala pouze jedna z větví rozsáhlejšího komplotu. Pro básníkův osud však tento posun neznamenal žádné ulehčení, nebot' dosavadní obvinění byla ze stranické úchylky překlasifikována do roviny kriminální. $^{5}$

Novomeský byl zatčen 6. února 1951 v rámci několikatýdenního zátahu, jemuž padly za obět' desítky stranických funkcionářò. ${ }^{6}$ Veřejnost se o jeho uvěznění dozvěděla až o dva týdny později. Na zasedání ústředního výboru KSČ 21. února 1951 přednesl generální tajemník ÚV KSS Š. Baštovanský zprávu O odhalení špionážnej záškodnickej činnosti V. Clementisa a o frakčnej protistranickej skupine buržoáznych nacionalistov $v$ KSS, kterou předtím schválilo předsednictvo ÚV KSČ. Jejich působení v ní vykreslil v tom nejodpudivějším světle: „Dnes je už jasne dokázané, že v celej činnosti Clementisa, Husáka a Novomeského nešlo o nejaké nesprávne ,chápanie 'otázok socializmu, ale že išlo o zámernú činnost' organizovanej zločineckej frakcie. [...] Výpoved' Clementisa a posledné výsledky vyšetrovania ukazujú, že ani u skupiny Husák - Novomeský nešlo teda $o$, chyby' a ,úchylky', ale že tu máme do činenia s organizovanou protistranickou frakcionárskou bandou, ktorá svojou separatistickou, podvratnou prácou

$5 \mathrm{~K}$ dobové interpretaci protistátního spiknutí viz projev Václava Kopeckého na Zasedání ústředního výboru Komunistické strany Československa ve dnech 21. - 24. února 1951 na Hradě pražském. Praha: ÚV KSČ, 1951, s. 167-203. K širším souvislostem srov. KAPLAN, Karel. Zpráva o zavraždění generálního tajemníka. Praha: Mladá fronta, 1992, s. 93-125. ISBN 8020402691; RYCHLİK, Češi a Slováci, ref. 3, s. 157-158; BARNOVSKÝ, ref. 3, s. 166-167.

6 Archiv bezpečnostních složek, fond (dále f.) Ministerstvo národní bezpečnosti, sign. ZV 66/1, Osobný spis štátnebezpečnostného vyšetrovania proti L. Novomeskému č. j. B/4-V-2449, Zpráva o zatčení L. Novomeského, 30. 6. 1951. 
vedome a úmyselne rozbijala jednotu Republiky a snažila sa v jej rámci fakticky udržat' t. zv. ,samostatný slovenský štát', aby vo vhodnej chvilli odtrhla Slovensko od Republiky, a ktorá zámerne hamovala vývin $k$ socializmu a orientovala sa $v$ podstate na reštaurovanie kapitalizmu. "7 $\mathrm{Na}$ základě těchto tezí Bašt'ovanský výrazně posunul interpretaci nacionalistické úchylky: „Buržoázny nacionalizmus dnes nie je len ideologickým prejavom vplyvu cudzej nepriatel'skej triedy $v$ radoch komunistických strán, nie je tedy len politickou úchylkou, ale z 99\% vlajkou agentov triedneho nepriatel'a a imperialistov pre rozvratnú a záškodnicku protistranícku a protištátnu činnost'. "8 Generální tajemník ÚV KSS celou skupinu obvinil z nenávisti k Sovětskému svazu a oznámil, že na všechny zajištěné byla uvalena vyšetřovací vazba. ${ }^{10}$ Nakonec předložil návrh, aby podobně jako Clementis byli i Husák a Novomeský vyloučeni z ústředního výboru KSČ, zbaveni poslaneckých mandátů a vyobcováni ze strany. Nejvyšší stranický orgán tato opatření jednomyslně schválil.

O dva měsíce později, 18. - 20. dubna 1951 se v Bratislavě sešlo plénum ÚV KSS, které předmětem svého jednání bezprostředně navazovalo na únorové zasedání ÚV KSČ. V hlavním referátu Viliam Široký zopakoval a dále rozvíjel závěry obsažené v Baštovanského projevu. ${ }^{11} \mathrm{Na}$ mnoha místech se také vrátil $\mathrm{k}$ vlastním argumentům, které pronesl na IX. sjezdu KSS. ${ }^{12}$ Jen jim dal mnohem razantnější a jednoznačnějšś interpretaci. Opětovně se uchýlil k pseudohistorické rétorice. Ideologické kořeny tzv. buržoazního nacionalismu sice spatřoval v meziválečném hnutí davistů, ale hned dodával, že jeho př́slušníci po zániku

7 Zasedání, ref. 5, s. 209.

8 Zasedání, ref. 5, s. 213-214.

9 Antisovětismus, původně předhazovaný pouze Clementisovi, se nově rozšśřil i na ostatní: „Bude tiež potrebné osobitne a podrobne preskúmat' pomer tejto skupiny k Sovietskemu zvä$z u$, odhalit' jej protisovietsku tvár, lebo viac priznakov nasvedčuje, že nielen Clementis, ale aj Husák a Novomeský boli a sú zarytými nepriatel'mi sovietskeho l’udu a jeho socialistického zriadenia. "Ref. 5, s. 209.

10 Odůvodnil ji následovně: „Pre úzke spojenie so záškodníkom, nepriatel’om a špiónom Clementisom a pre svoju rozvratnú činnost', ako aj so zretel’om na možnost' úteku do zahraničia, museli byt' vzatí do vyšetrovacej väzby aj Husák a Novomeský. "Ref. 5, s. 210.

11 V jeho úvodu pronesl předseda KSS tyto formulace: „Nebezpečná sprisahanecká banda bola zneškodnená a strana sa očistuje od zradných živlov. [...] V spojení s Clementisom bola odhalená protištátna a protistranicka frakčná činnost' Husáka a Novomeského, hlavných nositel'ov buržoázneho nacionalizmu v našej strane, ktorý bol podrobený zdrvujúcej kritike na našom slávnom IX. zjazde KSS. [...] Ich falošná maska spadla s tváre a objavili sa pred stranou, pred všetkým pracujúcim l’udom vo svojej pravej podobe: ako prisluhovači imperialistickej buržoáznej reakcie. "Slovenský národný archív (dále SNA), f. Komunistická strana Slovenska - Ústredný výbor (dále KSS-ÚV), karton (dále k.) 1824, plénum ÚV KSS, 18. - 20. 4. 1951, stenografický záznam, s. 4-5, 16-17.

12 SNA, f. KSS-ÚV, zjazdy a konferencie, k. 22, IX. zjazd KSS, 24. - 27. 5. 1950, stenografický záznam, referát V. Širokého, 24. 5. 1950, s. 57-66. 
Československa , prešli na stranu triedneho nepriatel'a, ako to máme dnes bezpečne zistené. Clementis v Parízi, Husák a Novomeský na Slovensku ". ${ }^{13}$ Všichni se za války ztotožnili s plány slovenské buržoazie a stali se jejími agenty. Husák a Novomeský jednali na př́mý popud Alexandra Macha, se kterým byli v úzkém kontaktu. Do odbojové činnosti se zapojili jen proto, ,, aby sa zmocnili vedenia strany a aby takto zachránili pozície Slovenského štátu ". ${ }^{14}$ Záměrně mařili př́pravy SNP, a když už mu nemohli zabránit, hájili při jeho průběhu pouze zájmy slovenské buržoazie. Ve stejné politice pokračovali i po osvobození, kdy se za každou cenu snažili udržet na Slovensku kapitalismus. Proto sabotovali všechna prijímaná opatření a hledali způsoby, jak uchovat v nezměněné podobě byrokratický aparát klerofašistického režimu.

Takzvaní buržoazní nacionalisté byli rovněž obviněni z protičeských postojů a separatismu. Jejich smyšlené úsilí o obnovu slovenského státu Široký postavil na roveň aktivitám nekomunistické emigrace, jak lud'ácké, tak demokratické: „Aký bol národnostný program Clementisa, Husáka a Novomeského, ako chceli hájit’ buržoázni nacionalisti národné záujmy Slovákov? Tak, že chceli odtrhnút' slovenský národ od bratstva a jednoty s českým národom, od bratstva, priatel'stva, spojenectva so Sovietskym zväzom. [...] Slovenski buržoázni nacionalisti teda dostali sa v podstate na tú istú platformu, ako Sidor a Ďurčanský, ako Lettrich a Kvetko, na platformu zrady národných záujmov, na platformu paktovania s americkými imperialistami, s nemeckými nacistami, lebo kto sa spojuje s Churchillom a Trumanom, spojuje sa súčasne súhlavnými nepriatel'mi slovenského národa. "15

Domnělá ideologická pochybení tak definitivně nabyla podoby trestných činů. Př́slušníci povstalecké garnitury KSS měli být v očích veřejnosti prezentováni jako zrádci a spolupracovníci tajné policie lud'áckého režimu, kteří válku přečkali bez úhony díky svým vazbám s př́slušníky establishmentu a v komunistické rezistenci plnili jen úlohu volavek ÚŠB ${ }^{16}$ Konstrukce o stycích s Machem, jež byla jedním z pilír̆u kriminální části teorie o tzv. buržoazně nacionalistickém spiknutí, objektivně poškozovala nejvíce právě Novomeského, který ministra vnitra slovenského státu občas navštěvoval za účelem intervencí ve prospěch komunistických odbojářů a netajil se tím. ${ }^{17}$

13 Ref. 11, s. 19.

14 Ref. 11, s. 21.

15 Ref. 11, s. 23-24.

16 V podobném duchu jako Široký se během pléna ÚV KSS na adresu tzv. buržoazních nacionalistů vyjádřili i ostatní hlavní řečníci - Štefan Baštovanský, Július Bránik a zvláště Rudolf Slánský.

17 Na tento aspekt upozorňuje v širších souvislostech zvláště RYCHLÍK, Češi a Slováci, ref. 3, s. $160-161$. 
Ostatně i Novomeský sám dostal na zasedání ÚV KSS od Širokého co proto. Předseda KSS podrobil ostrým odsudkům básníkovo poválečné účinkování ve školské a kulturní politice: „Novomeský úplne zámerne a systematicky pracoval k tomu, aby izoloval školstvo a celý kultúrny život od politiky strany, od politiky výstavby socializmu. [...] Školstvo pod vedením Novomeského bolo rezervoárom reakčných síl. Podobne pôsobili Husák a Novomeský v celom kultúrnom živote a najmä medzi inteligenciou. "18

Širokého vývody na adresu Novomeského v diskusi výrazně podepřel Ondrej Pavlík, který s básníkem do roku 1948 úzce spolupracoval jako zástupce pověřence a přednosta školské sekce pověřenectva školství a osvěty. ${ }^{19}$ Mohl tak vystupovat z pozice zasvěceného znalce, jehož argumenty mají patřičnou relevanci. Svého bývalého nadřizeného vykreslil jako intelektuálského povýšence odmítajícího marxismus-leninismus, zarytého odpůrce jednotné školy, ochránce církevních struktur, stoupence názoru o nadřazeném postavení inteligence vůči dělnické trrídě či jako př́vržence úpadkového formalistického umění. Svůj odsudek uzavřel: ,Jeho svetový názor je idealistický. [...] Vidíme u neho svornost buržóazneho nacionalizmu, kozmopolitizmu, náboženských predsudkov, a to $v$ nerozlučnej jednote. Nedivme sa potom, že nakoniec jeho ideológia viedla ho nutne $k$ zrade. Ani svojím chovaním, ani svojou básnickou tvorbou nikdy nebol komunistom. “20 Pavlíkovy „postřehy“ dále doplnili vedoucí kulturně-propagačního oddělení ÚV KSS Július Šefránek ${ }^{21}$ a stranický historik Miloš Gosiorovský. ${ }^{22}$

Na obou zasedáních ústředních výborů tak byly prezentovány základy konstrukce, ze které posléze vycházela obžaloba a rozsudek v procesu s tzv. slo-

18 Ref. 11, s. 22.

19 Více k tomu LONDÁKOVÁ, Elena. Ondrej Pavlík a prvá komunistická školská reforma v jej československých politicko-historických konotáciách. In MICHALIČKA, Vladimír SLEZÁKOVÁ, Miroslava (eds.). Ondrej Pavlik (1916 - 1996). Bratislava: Centrum vedecko-technických informácií SR, 2016, s. 23-31. ISBN 9788089354689.

20 Ref. 11, s. 203-215. Pavlík později uvedl, že nevybíravý obsah jeho řeči byl výsledkem manipulativního nátlaku Širokého a vlastního strachu ze zatčení. V roce 1956 svá tvrzení odvolal. PAVLÍK, Ondrej. Svedectvo dokumentov o akademikovi Pavlikovi a tých d'alšich. Bratislava: VPL, 1968, s. 21-23.

21 Šefránek rozebíral Novomeského „rozkladné“ působení v řadách slovenské inteligence. Za pomoci účelově vytržených citátů z jeho poválečných projevů mj. tvrdil, že bývalý pověřenec školství ještě roku 1946 veřejně hájil válečný slovenský stát a po únoru 1948 odvracel učitele od studia marxismu-leninismu. Ref. 11, s. 144-151.

22 Gosiorovský, který byl v historické práci autodidaktem, se pokusil vyztužit Širokého tezi o tom, že kořeny buržoazního nacionalismu sahají již do éry DAVu. Za pomoci vybraných úryvků z dopisů Petra Jilemnického Eduardu Urxovi z let 1925 a 1928 se snažil vzbudit dojem, že jen tito dva př́slušníci davistů byli přesvědčenými marxisty a že mezi nimi a zbytkem skupiny existovaly již tehdy zásadní ideové rozpory. Ref. 11, s. 304-309. 
venskými buržoazními nacionalisty. K justičnímu řízení však vedla ještě dlouhá cesta. Prvotním předpokladem jejího úspěchu měl být odsuzující hlas veřejného mínění. Roztočenou spirálu policejních represí proto gottwaldovská garnitura spojila s rozsáhlými ideologicko-propagandistickými opatřeními, s jejichž pomocí chtěla dovršit své dlouhodobé politické cíle: 1. definitivně zbavit bratislavské funkcionáře KSS posledních zbytků reálného vlivu, aby mohla ovládat stát pouze z jednoho mocenského centra; 2. razantně zastrašit všechny, kteří se v rámci republiky pokoušeli artikulovat specifické zájmy a potřeby Slovenska v oblasti politiky, hospodářství či kultury a neztotožňovali se s redukcí slovenské otázky na problematiku industrializace a ekonomického vyrovnání s českými zeměmi. ${ }^{23}$

Již únorové zasedání ÚV KSČ tudíž dalo podnět k zahájení nové kampaně proti tzv. buržoaznímu nacionalismu na Slovensku, která se s různou mírou intenzity vedla dalších dvanáct let. Směřovala především do řad inteligence. Útokům čelili zvláště ti její prŕslušníci, již byli od meziválečných dob spjati s davisty a po roce 1945 se významně podíleli na veřejném životě. Vedení KSS rozhodlo o spuštění propagandistického tažení již 3. března 1951. Baštovanský odůvodňoval tento krok na zasedáních stranických orgánů následovně: „,Husák, Novomeský a ich spoločníci svoje nebol'ševické náhl'ady a metódy rozširovali najmä medzi inteligenciou, ktorá je proti úchylkám menej imúnna, ako robotnícka trieda. [...] Liberalizmus a familiárnost'v ideologických otázkach [...] narobili nám obrovské škody vo vede, v literatúre, v umení a v školstve a sú hlavnou prekážkou zdravého rozvoja celej našej kultúrnej práce. Vplyvy protimarxistického a protileninského šarapatenia Novomeského a jeho pomáhačov neboli ešte plne odhalené a odstránené z nášho kultúrneho života. No, táto úloha je neodkladná a treba ju vykonat' [...] v súvislosti s preskúmavaním toho, ako boli v oblasti vedy, umenia, školstva a kultúry splnené uznesenia IX. zjazdu KSS. “24 „Čo my potrebujeme? My to musime spojit's vel'kou ideologickou kampaňou. Predpoklady sú [...] My musime mat' hlavne a v prvom rade jasno v robotnickej triede. Súčasne [urobime] vel'kú kampan̆ na ideologickom úseku medzi inteligenciou. Tam budú určité tažkosti. [...] Musime robit’ kampaň v štátnych úradoch, v poverenictvach, ale žiadne l'avé hlúposti. Po IX. zjazde sme urobili pol kroka, teraz to musime dokončit." "25

Kampaň proti tzv. buržoaznímu nacionalismu se tak záhy proměnila v nástroj personálních čistek, které $\mathrm{v}$ delším časovém horizontu a v různé míře postihly

23 LIPTÁK, L’ubomír. Slovensko v dvadsiatom storočí. IV. vydání. Bratislava: Kalligram, 2011, s. 279. ISBN 9788081015182.

24 Ref. 11, s. 76-77.

25 SNA, f. KSS-ÚV, predsedníctvo ÚV KSS, k. 803, 8. schůze, 3. 3. 1951, b. 1, kampaň po ÚV KSČ, protokol, s. 5. 
stovky lidí, at' už šlo o politické funkcionáře, odbojáře, vojáky, novináře, učitele, vědce či umělce. Zejména v prvních měsících byl její součástí téměř nepřetržitý proud útoků a pomluv na adresu postižených osob. Ani Novomeský se jim nevyhnul. Naopak se stal objektem totální ostrakizace. Jeho osoba i dílo měly být vymazány z kulturního povědomí, popřípadě připomínány pouze s pohrdáním a odsudky. Krátce po básníkově zatčení sekretariát ÚV KSS rozhodl o tom, aby se Novomeského publicistické práce stáhly z knihoven, knižních skladů a knihkupectví. Jeho verše musely zmizet z nových vydání učebnic a bylo zakázáno je recitovat ve školách i na veřejnosti. Básnické sbírky nemohly vycházet v reedici. Umělcův význam pro vývoj slovenské poezie nesměl být připomínán. ${ }^{26}$

Stranický aparát samozřejmě nespoléhal jen na vlastní restriktivní opatření. Od počátku usiloval také o to, aby Novomeského ostentativně zatratili přední intelektuálové a představitelé kulturních a vědeckých institucí. Mnozí z nich se totiž s básníkem dlouhá léta znali a spolupracovali s ním, uznávali jeho poezii i literární názory, respektovali ho jako politickou autoritu a podporovali jeho tolerantní pojetí poválečné kulturní politiky. Jejich nynější odsuzující stanovisko tak mohlo posílit důvěryhodnost rozpoutávané kampaně. Největší očekávání v tomto směru spojovalo vedení KSS se slovenskými literáty. Př́ččny lze snadno odvodit. Novomeský patřil k jejich špičce a navíc v letech 1945-1948 stál v čele Spolku slovenských spisovatelů. V rámci uměleckých kruhů představovali literáti nejpočetnější skupinu, jejíž díla disponovala vysokou rezonancí ve společnosti. Jejich nové stavovské sdružení Slovenská sekce Svazu československých spisovatelů (SČSS) měla výsadní postavení mezi tvůrčími organizacemi. Spisovatelé komunisté byli považováni za prední reprezentanty ideologického aktivu KSS. Zároveň však od konce čtyřicátých let čelili rostoucímu tlaku, aby svou tvorbu přizpůsobili schematickým normám politicko-estetické doktríny socialistického realismu a plánovitě vycházeli vstříc společenské objednávce, zbavili se ,individualismu“ a neblahého dědictví „formalistických“ uměleckých směrů, a svými literárními počiny i aktuální publicistikou se iniciativně zapojovali do dobových propagandistických kampaní. Dosavadní míru ochoty, s níž se spisovatelé snažili vyjít vstříc těmto požadavkům, však vládnoucí establishment nepovažoval za dostačující. Útok proti tzv. buržoaznímu nacionalismu měl být proto ve Slovenské sekci SČSS spojen s kádrovými změnami a nesmlouvavou kritikou těch tvůrců, kteří měli k Novomeskému blízko a zároveň mezi lety 1945-1949 spoluvytvářeli nedogmatickou linii KSS v oblasti kultury a vědy.

V pogromistické atmosfére počátku jara 1951 tak byli spisovatelé, a s nimi i řada dalších prŕslušníků inteligence, postaveni před osudovou volbu: bud' se

26 Totální embargo postihlo také všechny knihy Clementise a Husáka i monografii Vladimíra Reisela Poézia Laca Novomeského z roku 1946. SNA, f. KSS-ÚV, sekretariát ÚV KSS, k. 16, 10. schůze, 16. 3. 1951, b. 12, návrh na stiahnutie kníh Clementisa a spol. 
Novomeského zastanou a budou riskovat obvinění ze zrady socialismu, nebo se podvolí tomu, co po nich moc žádá. Zpravidla se rozhodli pro druhou možnost. ${ }^{27}$ Někteří, zvláště zástupci mladé budovatelské generace tak učinili v slepé víře $\mathrm{v}$ „neomylnost“ strany, jiní z kariérismu, oportunismu či pod nátlakem. Chování většiny však ovlivňoval především rostoucí strach z represí, který podlamoval jejich vůli k odporu. ${ }^{28}$ Vyslovení vlastních názorů mohlo mít pro jednotlivce fatální následky. A tak místo nich zazněly četné proklamace loajality, demonstrující neochvějnou víru v poúnorový režim a jeho ideologii ${ }^{29}$ Největším gestem vzdoru tak bylo výmluvné mlčení. Své skutečné názory si intelektuálové sdělovali v nejužším soukromí, svá traumata $\mathrm{z}$ vlastní bezmoci potajmu svěřovali listům papíru, které nikdo nesměl spatřit. ${ }^{30}$

Slovenští spisovatelé přitom nebyli s tažením proti nacionální úchylce konfrontováni poprvé. Zapojili se do něj již na jaře 1950, kdy se na svazovém aktivu a v sérii statí deklarativně přihlašovali k odsudkům, které na adresu Novomeského a spol. zazněly z politických míst. Na popud stranických struktur je doplňovali kritickým hodnocením role davistů ve vývoji slovenské literatury. ${ }^{31}$ Pronášené výpady však měly pouze všeobecný charakter a zpravidla nebyly spojeny s osobními útoky na odstavené funkcionáře. ${ }^{32}$ Zatčení tzv. buržoazních naciona-

27 Danou problematiku v kontextu literárních a kulturních dějin přelomu čtyřicátých a padesátých let podnětně analyzují PETRÍK, Vladimír. Proces \& tvorba. Bratislava: Slovenský spisovatel', 1990, s. 55-74. ISBN 802200152; BÍLIK, René. Industrializovaná literatúra (1945 - 1956). Bratislava: Proxy, 1996, s. 23-28. ISBN 8088746043; DRUG, Štefan (ed.). Umenie v službách totality 1948 - 1956. Bratislava: Ústav slovenskej literatúry, 2001, s. 20-28. ISBN 8088746132 .

28 Ochromující ovzduší tehdejší doby zachytil ve své vzpomínce nap̌r. Ladislav Mňačko: „Prišiel som do bratislavského Carltonu, do kaviarne. Sedel tam kritik František Votruba. Mal vel’mi rád Laca Novomeského [...] a ked' ma [...] uvidel, vyskočil zo stoličky a kýva mi Pravdou, kričí: ,Čo tomu hovorís, čo tomu hovorišs? 'V Pravde bola na prvej strane správa, že Husák, Novomeský a d’alši boli zatvorení a obvinení za buržoázny nacionalizmus. Potom si tak skrúšene, sklesle sadol, odmlčal sa, len po chvili prehovoril: ,No, ale ideme d'alej, ideme d'alej... 'Taký čistý, až svätý človek [...] prepadol strachu. Aj ja som mal strach. " Ako chutí samota. In Literárny týždenník, 1989, roč. 2, č. 51-52, s. 14. ISSN 0862-5999. Navzdory výše uvedenému (anebo právě proto) se Mňačko do diskreditační kampaně také zapojil.

29 LONDÁKOVÁ, Elena. Nevinní vinníci - obžalovaní a ich obete. Odraz kampane proti „,buržoáznym nacionalistom“v slovenskom kultúrnom živote. In Soudobé dějiny, 2002, roč. 9, č. 3-4, s. 484. ISSN 1210-7050.

30 Poutavé verše, zachycující nelidskost éry stalinismu, psal do šuplíku např. básník Ján Smrek, který byl po únoru 1948 vytlačen na okraj veřejného života. Reflektoval v nich i neblahý osud Novomeského, se kterým ho pojilo dlouholeté přátelství. SMREK, Ján. Proti noci: Básne vnútorného exilu. Bratislava: Elán, 2010, s. 36. ISBN 9788096959143.

31 Podrobněji viz PETRÍK, ref. 27, s. 60-64; BÍLIK, ref. 27, s. 25-27; DRUG, ref. 27, s. 24-26.

32 Srov. rezoluci z aktivu a texty Michala Chorvátha, Vladimíra Mináče, Ctibora Štítnického a zvláště Juraje Špitzera. In Kultúrny život, 1950, roč. 5, č. 8, s. 1 a 3; č. 9, s. 1-3; č. 12, s. 1 
listů muselo spisovatele nesporně šokovat. A současně jim dalo tvrdě pocítit, že dosavadní, relativně uměřená míra angažovanosti již nebude stačit. Navzdory tomu však prvotní reakce vedení svazu vyzněla poněkud rozpačitě. Předseda Slovenské sekce SČSS a šéfredaktor Kultúrneho života Michal Chorváth se sice pateticky přihlásil $\mathrm{k}$ výsledkům únorového zasedání ÚV KSČ a oddaně dodal, že ,'musime s konečnou dôslednost'ou - so železnou metlou - vymiest' zvyšky buržoázneho nacionalizmu [... a dat'] svoje perá do služieb odhal'ovania zrady, špionáže, pažravosti, nedôvery a váhavosti “, ale obsah Bašt’ovanského referátu zcela obešel a vyhnul se jakýmkoliv atakům vůči Novomeskému. ${ }^{33}$ Také jeho druhý úvodník, uveřejněný o týden později, nevynikal př́iliš konkrétností. ${ }^{34}$

Pracovníci aparátu ÚV KSS dali zřejmě Chorváthovi záhy najevo, že hra na schovávanou již skončila a literáti musí k „demaskování zrádcư“ zaujmout jednoznačné stanovisko. Výbor Slovenské sekce SČSS poté 12. března 1951 danou záležitost projednal a jednomyslně podpořil Chorváthův návrh na Novomeského vyloučení ze svazu spisovatelů. Zároveň schválil prohlášení, které s básníkem zúčtovalo v intencích Baštovanského projevu na plénu ÚV KSČ: , Ladislav Novomeský spojil sa so záškodníkmi a zákernými agentmi vojnového tábora a spolu s nimi pripravoval rozvrat a záhubu l'udovodemokratickej Republiky. Tým zradil pracujúci l’ud, poškodil jeho úsilia a maril jeho boj za nový, lepši život. Od začiatku svojho literárneho pôsobenia $v$ skupine DAV presadzoval Novomeský tendencie, nezlučitel'né s úlohami revolučného spisovatel'a a tým napomáhal odklonu od vel'kých realistických tendencií našej literatúry. Uvedomele a rafinovane propagoval protivlastenecké, kozmopolitické tendencie $v$ našom umení a orientoval literatúru na hnilobné výhonky kapitalistickej kultúry, aby ju postavil do služieb triedneho nepriatel'a. " Proklamace dále konstatovala, že Novomeský nenáviděl český národ i Sovětský svaz a podceňoval jejich literatury, mařil na Slovensku vývoj k socialistickému realismu, podkopával práci spisovatelského svazu, nebot' mu šlo o ,vedomé zneužitie kultúry a najmä literatúry pre zločinné ciele sprisahancov " ${ }^{35}$ Prokurátorskou dikci provolání doplnil ještě článek literárního kritika Alexandra Matušky, který se otevřeně přihlásil k Baštovanského vývodům a plamenně dodal: ,, ... čo začalo literatúrou, skončilo sa protištátnou

a 3. Se zpožděním se ke kampani připojili také divadelníci, výtvarníci a vědečtí pracovníci.

CHORVÁTH, Michal. Slova múdrosti a sily. In Kultúrny život, 1951, roč. 6, č. 9, s. 1-2.

CHORVÁTH, Michal. Bdelost' a ostražitost'. In Kultúrny život, 1951, roč. 6, č. 10, s. 1 a 3. Ostatně není se čemu divit, nebot' Chorváth byl již od třicátých let s Novomeským spojen četnými pracovními i lidskými vazbami.

35 Kultúrny život, 1951, roč. 6, č. 11, s. 1. Pouze ústřední stranický deník ovšem uveřejnil konkrétní signatáře prohlášení. Podepsali ho: Michal Chorváth (předseda), Ctibor Štítnický (tajemník), Krista Bendová, Ján Brezina, Margita Figuli, Ján Ferenčík, František Hečko, Pavol Horov, Ján Kostra, Ivan Kusý, Milan Lajčiak, Vladimír Mináč, Andrej Plávka, Ján Rak, Karol Rosenbaum a Dominik Tatarka. Pravda, 1951, roč. 32, č. 62, s. 2. 
činnost'ou a zradou. Odhalenie zradcovskej skupiny Clementis, Husák, Novomeský je vel'kou výstrahou pre tých, čo sú ešte zahl'adeni do kozmopolitického bahna a nestriasli ešte prašivinu buržoázneho nacionalizmu: je vel'kou príležitostou $k$ samokritickej očistnej revízii “. ${ }^{36}$

Prohlášení slovenské sekce SČSS bylo signálem k tomu, aby se od Novomeského distancovaly další instituce, které s ním dlouhodobě spolupracovaly. Učinily tak Slovenská akademie věd a umění ${ }^{37}$ i Matice slovenská. ${ }^{38}$ Ve druhé z nich se patrně koncem března 1951 konala celozávodní schůze všech zaměstnanců, která jednomyslně navrhla matiční Správě, aby básníka vyškrtla ze seznamu členů a tím ho zbavila i úřadu př́edsedy. ${ }^{39}$ Matiční představitelé, kteří měli obavy o další osud instituce, raději svůj postup nejprve konzultovali s pověřencem informací a osvěty Ondrejem Klokočem. Po poradě s ním se rozhodli ,vypracovat' elaborát, v ktorom sa odsúdi činnost' Novomeského a jeho spoločníkov “ a oznámí vyloučení Clementise, Husáka a Novomeského z Matice slovenské, čímž bude bývalý pověřenec školství z předsednické funkce odstraněn. Zároveň se usnesli vyhledat všechny projevy a články, jež Novomeský jako vedoucí činitel Matice přednesl, a podrobit je veřejné kritice..$^{40}$ Všechny tyto aktivity zaštitoval správce Matice Ján Marták, který s básníkem po roce 1945 pravidelně konzultoval většinu jejích aktivit. ${ }^{41}$

Od počátku března 1951 se k pranýřujícímu chóru postupně přidávali agilní jednotlivci z řad novinářů a spisovatelů (zvláště z nejmladší generace), byt’ motivy jejich konání byly patrně velmi různorodé. Zatímco šéfredaktor stranického týdeníku Nové slovo Mieroslav Hysko ${ }^{42}$ a tehdejší zahraničněpolitický reportér Pravdy L. Mňačko ${ }^{43}$ rozebírali tzv. buržoazní nacionalismus v kontextu mezinárodních protisovětských spiknutí, literární a divadelní kritik Ján Rozner se zamýšlel nad Novomeského aktivitami od dvacátých let. Př́krými slovy napadl jeho poetickou tvorbu a zvláště kulturněpolitické statě. Zcela dezinterpretoval smysl básníkova vystoupení na kongresu slovenských spisovatelů v Trenčianskych Tepliciach roku 1936 i série článků ve válečném Elánu. Označil ho za

36 Zrada literatúry a l’udu. In Kultúrny život, 1951, roč. 6, č. 11, s. 1.

37 Srov. DOSKOČIL, ref. 4.

38 Novomeský byl od roku 1945 jejím předsedou.

39 DRUG, ref. 2, sv. II., s. 592.

40 Archív Matice slovenskej, f. Matice slovenská, III., presidium MS 1951, k. 1, inv. j. 11, Zápisnica zo zasadnutía Správy Matice slovenskej 26. 4. 1951 a 26. 6. 1951.

41 Z dostupných pramenů a literatury však nelze jednoznačně určit, zda byl básník zbaven členství v Matici či nikoliv. DRUG, ref. 2, sv. II., s. 592; WINKLER, Tomáš - ELIÁŠ, Michal et al. Matica slovenská: Dejiny a prítomnost'. Martin: Matica slovenská, 2003, s. 165. ISBN 8070906944.

42 Nezapisuj svoju dušu diablovi. In Nové slovo, 1951, roč. 8, č. 12, s. 221-223.

43 Stromy zrady nerastú do neba. In Pravda, 1951, roč. 32, č. 65, s. 5. 
odpůrce angažovaného umění, defétistu, který pozvolna podlehl vlivům maloměštáctví a buržoazní ideologie, čímž dlouhodobě zpomaloval vývoj slovenského kulturního života směrem k socialismu. A svou „analýzu“ uzavřel: „,Za situácie zostrujúceho sa boja s triednym nepriatel'om Novomeský od kompromisníctva a malomeštiackej polovičatosti skončil pri otvorenej zrade, od odcudzenia strane v priamom nepriatel'stve $k$ strane, od obdivu ku, kultivovanosti 'dekadentnej buržoázie v priamom nadbiehaní imperialistom. A tak sa Novomeský ocitol na druhej strane barikády - na fronte nepriatel'ov nášho l'udovodemokratického režimu, nepriatel'ov socializmu. "44 $\mathrm{V}$ podobném duchu se $\mathrm{k}$ bývalému pověřenci školství vyslovil teprve pětadvacetiletý a režimem protežovaný socrealistický básník Milan Lajčiak: ,, Novomeský kormidloval literatúru nie do služieb všeproletárskej veci, ale do služieb slovenskej buržoázie na jednej strane a do služieb kozmopolitickej bezpáternosti na druhej strane. "45 Jádro jeho úvodníku však směřovalo proti čtveřici tvůrců (M. Chorváth, A. Matuška, V. Mináč, D. Tatarka), kteří byli obviněni z hlásání nepřátelské ideologie a podléhání vlivům tzv. buržoazního nacionalismu. ${ }^{46}$ Předznamenalo personální zemětřesení ve svazu spisovatelů a naznačilo, že objektem propagandistické kampaně nebudou jen uvěznění straničtí předáci. ${ }^{47}$

Počátkem jara 1951 byla $\mathrm{v}$ celé společnosti cíleně navozována atmosféra odplaty. Na základě pokynů partajního aparátu čelily ústřední úřady i média záplavě prohlášení jednotlivců, pracovních kolektivů či organizací KSS všech úrovní, které ve vztahu k Clementisovi, Husákovi a Novomeskému překypovaly

44 Prekonat’ vplyv buržoázneho nacionalizmu v oblasti kultúry. In Pravda, 1951, roč. 32, č. 68, s. 6-7. Rozner byl v letech 1945-1948 redaktorem Národnej obrody a posléze Pravdy. Po únorovém převratu patřil k předním marxistickým kritikům, ačkoliv nikdy nevstoupil do KSČ. Osobitou reflexi svého působení v ústředním stranickém deníku podal v knize ROZNER, Ján. Sedem dni do pohrebu. 2. vydání. Bratislava: Albert Marenčin PT, 2010, s. 108-113. ISBN 9788081140709.

45 Proti buržoáznemu nacionalizmu a kozmopolitizmu, za vyššiu ideovost' našej literatúry. In Kultúrny život, 1951, roč. 6, č. 13, s. 1.

46 Zatímco u Mináče a Tatarky napadl Lajčiak pouze vybraná umělecká díla, v př́ípadě Chorvátha a Matušky odsoudil celou jejich literárně kritickou činnost. Chorváthovi navíc vytkl, že v úvodnících, jež napsal po únorovém zasedání ÚV KSČ, propadl ,,nebol'ševickému, panikárskemu postoji “. Ref. 45. Více k tomu PETRÍK, ref. 27, s. 74-76; DRUG, Štefan. Literatúra a politika po slovensky. Bratislava: Slovenský spisovatel', 2003, s. 110-111. ISBN 8022012661.

47 Lajčiak vycházel z referátu pracovníka kulturně-propagačního oddělení ÚV KSČ Pavla Reimana, který na zasedání Ústřední ediční rady 21. března 1951 podrobil poměry ve slovenské literatuře ostré kritice. Lze z toho usuzovat, že rozpoutání tažení proti tzv. buržoaznímu nacionalismu v širším měřítku nebylo jen výsledkem iniciativy bratislavských funkcionářů, ale vycházelo i z podnětů pražského stranického aparátu. Zmíněné okolnosti blíže analyzuje DRUG, ref. 27, s. 29-31. 
nenávistí i pohrdáním a žádaly pro ně tvrdé tresty. ${ }^{48}$ Také pověřenectvo školství, věd a umění obdrželo stovky telegramů, dopisů a rezolucí, v nichž se vedení škol, učitelské sbory i žáci rázně vyrovnávali se svým někdejším představeným. Hysterické ovzduší pozdního stalinismu velmi plasticky ilustrovaly zvláště vyjádření nejmladších dětí, neuměle a kostrbatým rukopisem reprodukující oficiální floskule, jejichž obsahu a smyslu sotva mohly porozumět. Například žáci třetí třídy Národní školy ve Zborově nad Bystricou museli napsat, že ,,sme vd'ační za to, že komunistická strana odhalila zradcov Novomeského a ostatných. $V$ škole sa o nich učime ako aj o amrických (sic!) kapitalistoch. Oni chcú vojnu a my vojnu nechceme. Reakcionári sú zlí l'udia. Preto chceme, aby boli prísne a spravodlivo potrestaní. Až budeme vel'ki i my chceme byt' komunisti a údernici. Teraz v škole chceme sa dobre učit', aby sme ubránili mier a pomohli budovat' socializmus. Práci čest!! “49 Všechny proklamace se zároveň zaklínaly oddaností prezidentu Gottwaldovi, KSČ, lidově demokratickému zřízení, Sovětskému svazu, soudruhu Stalinovi atd. Tato vynucená gesta loajality byla občas doplňována sebemrskačskými dopisy, v nichž se bázní zachvácení členové KSS káli za své předchozí politické i osobní sepětí s buržoazními nacionalisty. ${ }^{50}$

Pádnost vynášených odsudků, které se objevovaly v dobovém tisku, vyztužovala „umělecká“ díla. Malír Štefan Bednár uveřejnil v Novém slově sérii karikatur zesměňňujících Novomeského toleranci k formalistickému umění i jeho odbojovou činnost. ${ }^{51}$ Pomyslné dno ale představoval nenávistný básnický výtvor M. Lajčiaka Horúcim perom. Bez sebemenších skrupulí ve verších parafrázoval a dále vyhrocoval argumenty, jež proti zatčeným představitelům KSČ a KSS zazněly na vrcholných partajních fórech. Nazval je ,vrahy a poběhlicemi bez duše ", kteří zradili stranu a usilovali o život K. Gottwalda. Poté, co si vyřídil svůj účet s M. Švermovou a vyjádřil radost nad Clementisovým uvězněním, vypořádal se tvrdě také s Novomeským: ,,Ked'spomeniem si na básnika, / čo vedel víno zrady pit', / už nemám rytmu, ani rýmov, / ani jemnocit. / Dopísal pašovanou ceruzkou / kompozíciu s prašivinou / a nenapíše ani dobrý nekrológ. / Tak ako žil, bez chrbtovej kosti, šmajchl'ujúci sa anarchii, / Eiffelovke, / obdivujúci troc-

48 Stránky ústředního stranického deníku se od konce února 1951 téměř každý den plnily květnatou frazeologií těchto provolání.

49 SNA, f. Povereníctvo školstva, písomnosti povereníkov, k. 29, inv. č. 55.

50 Patřil mezi ně např. pověřenec zemědělství Michal Falt’an, který poté, co předsednictvo ÚV KSS rozhodlo o rozpoutání tažení proti tzv. buržoazním nacionalistům, adresoval Baštovanskému v březnu 1951 dopis, v němž rozebral ,,mne známe veci z činnosti Husáka a Novomeského, ktoré potvrdzujú ich frakčnú protistranícku činnost' a dokresl'ujú ich v podstate l'udácku tvár “. SNA, f. KSS-ÚV, generálny tajomník ÚV KSS Štefan Baštovanský, k. 2121, arch. j. GT 46/2.

51 Viz Nové slovo, 1951, roč. 8, č. 11, s. 203; č. 13, s. 252; č. 18, s. 353. Na obálce otiskl karikaturu také satirický týdeník Roháč, 1951, roč. 4, č. 10, s. 1. 
kistický hmyz, / zahynie, bez lásky zomrie, / ako žili / kamaráti z mokrej štvrte, / Doktor Husák a Mach perohryz. "52 Při četbě těchto krutých slov se historik nemůže vyhnout otázce, co Lajčiaka motivovalo k jejich napsání. Skálopevně věril straně? Jednal v zájmu své strmě stoupající kariéry? Anebo byl za vším jen bezcitný, surový cynismus? ${ }^{53}$

Vedení KSS takovouto osobní iniciativu umělců samozřejmě vítalo. Zároveň však již od počátku chtělo z rozpoutaného běsnění vyloučit jakoukoliv nahodilost a dát kampani proti tzv. buržoaznímu nacionalismu $\mathrm{v}$ řadách inteligence pevný řád a jasné ideologické mantinely. Brzy totiž postřehlo, že Slovenská sekce SČSS se Novomeského otevřeně zřekla až po určitém váhání a její představitelé (Chorváth, Matuška), kteří měli jít příkladem ostatním tvưrčím svazům, se ve svých vyjádřeních na adresu „zrádcư“ více méně jen drželi oficiálních usnesení a vytvořenou konstrukci argumentačně př́lišs neobohatili. Jakmile zjistilo, že poměry uvnitř literární obce vyvolaly nelibost v pražském stranickém aparátu, rozhodlo se okamžitě jednat a předním intelektuálům ,pomoci“ k zaujetí správného stanoviska. ${ }^{54}$ Sekretariát ÚV KSS proto 23. března 1951 uložil pracovníkům kulturně-propagačního oddělení (Július Šefránek, Juraj Špitzer) „pripravit' a rozvinút medzi spisovatel'mi vel'kú ideologickú kampan̆ na ozdravenie pomerov v slovenskej literatúre, zameranú najmä proti buržoáznemu nacionalizmu a kozmopolitizmu “, kterou doplňovala série kádrových opatření ve svazu spisovatelů. ${ }^{55}$ Současně schválil plán rozsáhlé agitační akce mezi kulturními pracovníky, odhalující zhoubný vliv Clementise, Husáka a Novomeského na slovenský kulturní život, uměleckou tvorbu i samotné tvưrce. Impuls k jejímu zahájení měl dát aktiv spisovatelů komunistů, na nějž byli přizváni zástupci ostatních tvůrčích svazů. Ti potom měli svolat vlastní schůze a přijmout na nich

52 Kultúrny život, 1951 , roč. 6 , č. 16, s. 5.

53 Nad tímto aspektem se zamýšlí DRUG, Štefan. Symbióza poézie s politikou po druhej svetovej vojne, 2. čast'. In Slovenská literatúra, 2001, roč. 48, č. 3, s. 222. ISSN 0037-6973.

54 Vedoucí kulturně-propagačního oddělení ÚV KSS J. Šefránek hodnotil situaci ve svazu spisovatelů neobyčejně kriticky. Jeho vedení ,,nepracuje v duchu uznesení IX. zjazdu KSS a neplní úlohy uložené zjazdom “, týdeník Kultúrny život „,sa prepožičal k uverejňovaniu vyslovene provokatívnych, nepriatel'ských a štvavých článkov". Jejich autoři (např. V. Mináč, D. Tatarka, A. Matuška) „,nestoja na pôde marx-leninizmu“ a ve své tvorbě „propagujú i nad'alej buržoáznu ideológiu“. Za činnost těchto tvůrců nese odpovědnost předseda Slovenské sekce SČSS M. Chorváth, který dovolil, aby ,,vo zväze spisovatel'ov a v literatúre nad’alej šarapatili nositelia buržoázneho nacionalizmu“. SNA, f. KSS-ÚV, sekretariát ÚV KSS, k. 17, 16. schůze, 26. 4. 1951, b. 19, Návrh na zamestnanie kritizovaných spisovatel'ov, př́loha Niektoré opatrenia v slovenskej sekcii Zväzu čs. spisovatel'ov a vo vydavatel'skej činnosti, 21. 3. 1951, s. $1-2$.

55 Tamtéž, k. 16, 12. schůze, 23. 3. 1951, b. 5, Niektoré opatrenia vo Zväze spisovatel’ov, s. 2-3. Chorváth byl odvolán z čela Slovenské sekce SČSS (jejím předsedou se v květnu 1951 stal Lajčiak) a zbaven funkce šéfredaktora Kultúrneho života. 
odsuzující rezoluce. ${ }^{56}$ Kromě toho bylo redaktorům rozhlasu a Nového slova nařízeno, aby k problematice tzv. buržoazního nacionalismu připravili blok příspěvků zaměřených na dílčí témata. ${ }^{57}$ Sérií těchto opatření hodlalo vedení KSS „ideově upevnit" novinářské řady i všechny umělecké organizace a přimět je k intenzivnějšímu boji ,s neprátelskými ideologiemi“.

Na spisovatelském aktivu, který se sešel 30. - 31. března 1951, vystoupil s hlavním referátem vedoucí kulturně-propagačního oddělení ÚV KSS J. Šefránek. Konstrukci o tzv. buržoazním nacionalismu, kterou Široký a Baštovanský prezentovali na IX. sjezdu KSS a únorovém zasedání ÚV KSČ, v něm aplikoval do oblasti literatury a kultury. Ve ždanovovském duchu se pokusil o podrobnou ideologickou analýzu Novomeského básnické a publicistické tvorby na pozadí aktivit celé skupiny davistů, jež nesmlouvavě odsoudil. ${ }^{58}$ Vycházel přitom z apriorní teze, že Novomeský je usvědčený „zrádce“, a svými argumenty se snažil publiku předložit dodatečné „důkazy“, které by tuto základní premisu podepřely a dodaly jí na věrohodnosti. ${ }^{59} \mathrm{~V}$ úvodu svého proslovu poznamenal, že komunisté musí svést ideologický zápas proti škodlivým následkům ,,buržoázneho nacionalizmu vo všetkých oblastiach nášho života a pritom aj vybrat' reakčné hniezda, ktoré [jeho] predstavitelia chránili [...] najmä v oblasti kultúry“. Je proto nutné zabývat se jeho minulostí a zcela přehodnotit historickou roli davistů, zvláště Clementise a Novomeského, nebot' tato skupina a její časopis měly „neblahý vplyv na l'avú inteligenciu a špeciálne aj na slovenskú literatúru a kultúru ". ${ }^{60} \mathrm{Z}$ davistického hnutí utilitárně vyčlenil Petra Jilemnického a Eduarda Urxe, kteří „, sa nedali strhnút’ na scestie“, zůstali věrni Sovětskému svazu, mar-

56 Tamtéž, b. 10, Plán agitačnej a propagačnej kampane po ÚV KSČ.

57 Články měly přehodnotit historickou roli davistů či interpretaci SNP, analyzovat dopad tzv. buržoazního nacionalismu na školství, vědu a kulturu.

58 U Šefránka je nutné se aspoň pár slovy zastavit. S Novomeským se dlouhé roky znal. Od konce dvacátých let společně pracovali v redakcích Pravdy a Rudého práva, později v Ludovom denniku a Slovenských zvestiach. Šefránek také prŕležitostně přispíval do $D A V u$. Za slovenského státu, kdy pro svůj židovský původ ztratil zaměstnání i velkou část rodiny, posílal články do týdeníku Budovatel', který Novomeský redigoval. Před koncentračním táborem Šefránka zachránilo manželství s árijkou. Zúčastnil se SNP. Po válce byl krátce šéfredaktorem Pravdy, odkud odešel do stranického aparátu. Viz RUTTKAY, Fraňo. Július Šefránek - komunistický redaktor a publicista. In Sešity novináře, 1981, roč. 15, č. 1, s. 101-132. ISSN 01399411; DRUG, ref. 2, sv. II., s. 166; DRUG, Štefan. Kapitoly z l'udských a literárnych dejín pohnutých čias. In PEKNÍK, Miroslav - PETROVIČOVÁ, Eleonóra. (eds.). Laco Novomeský - kultúrny politik, politik v kultúre. Bratislava: Veda, 2006, s. 231. ISBN 8022409022.

59 Nebyl přitom př́liš originální, nebot' přebíral a dále rozvíjel názory z již publikovaných Roznerových a Lajčiakových statí.

60 Údajně škodlivé působení $D A V u$ na slovenskou inteligenci Šefránek záměrně přeceňoval. Časopis díky finančním těžkostem vycházel nepravidelně a v malém nákladu. Jeho čtenářská obec byla značně omezená, jelikož permanentně bojoval s nedostatkem předplatitelů. 
xismu-leninismu i dělnické třídě. Publicistiku $D A V u$ ostře kritizovali. Ostatní davisté však šli jinou cestou. Především Clementis a Novomeský si již od dvacátých let nárokovali „vždy osobitné, privilegované, intelektuálske postavenie $v$ strane", povyšovali se nad dělnickou třídu, její aktivity pouze komentovali $\mathrm{z}$, intelektuálskej vzdialenosti“ a byli přívrženci pokryteckého učení o vedoucí úloze inteligence ve společnosti. K marxisticko-leninské teorii měli velmi povrchní vztah. Clementis byl , salónnym [...] marxistom, [...] Novomeský sa štúdiu marxizmu-leninizmu jednoducho nikdy nevenoval a nepokladal to ani za potrebné. V tom sa stal jeho verným nasledovníkom Husák, ktorého negatívny pomer k marxizmu bol známy“. Nelze se potom divit, že přes politické kolísání, chyby a úchylky nakonec všichni tři dospěli ke zradě a přechodu do tábora nepř́tele. Kvůli své názorové nepevnosti davistická skupina dlouhodobě negativně ovlivňovala slovenský veřejný život. ${ }^{61}$ Od třicátých let se vyznačovala , širokým buržoázno-nacionalistickým taktickým pláštom “, pod nímž se spojovala také s ,, vyslovenou slovenskou reakciou "včetně lud'áckých autonomistů. Učinila tak již na trenčianskoteplickém sjezdu „,mladé slovenské generácie“"v roce 1932 a ve stejném duchu pokračovala za slovenského státu i po osvobození. ${ }^{62}$

Vedoucí „,agitpropu“ dále bryskně odmítl představu o davistech pomáhajících vytvořit slovenskou moderní literaturu. Nepopíral sice, že zpočátku koketovali se socialistickými ideály, ale brzy se pod vedením Novomeského obrátili ke kosmopolitismu. Zmátli řadu slovenských spisovatelů, kteří se pokládali za pokrokové, a orientovali je na „zahnívajúcu buržoáznu kultúru Západu“ vyznačující se anarchismem, individualismem a surrealismem. Vykonali tak ,, tú istú reakčnú prácu, ktorú urobil v Devětsile [Karel] Teige “ ${ }^{63}$ A výmluvně dodal: ,, buržoázny

61 Z jejich dalších př́islušníků Šefránek napadal Daniela Okáliho a Jána Poničana.

62 Trenčianskoteplického sjezdu se v červnu 1932 zúčastnili mladí intelektuálové z různých politických proudů (l’udáci, agrárníci, komunisté). Navzdory názorové diferenciaci většina účastníků při debatě o postavení Slovenska v ČSR vesměs kritizovala ideu československé národní jednoty a centralistické uspořádání státu. Přimlouvala se za jistou autonomii pro Slovensko. Opoziční vyznění sjezdu a podíl Clementise, Novomeského a Okáliho na něm se počátkem padesátých let interpretovaly jako počátek otevřené politické spolupráce davistů se slovenskou buržoazií a l’udáky a důkaz jejich „zrady“. Tuto smyšlenou tezi, která se později stala nedílnou součástí trestněprávní konstrukce procesu s tzv. slovenskými buržoazními nacionalisty, poprvé použil právě Šefránek. Ve skutečnosti se davisté zúčastnili sjezdu se souhlasem vedení KSČ, jež na něj vyslalo i svého delegáta Václava Kopeckého. Podrobněji HOLOTÍKOVÁ, Zdenka - PLEVZA, Viliam. Vladimír Clementis. Bratislava: VPL, 1968, s. 100-109; HOLOTÍKOVÁ, Zdenka. Ladislav Novomeský. Bratislava: Pravda, 1981, s. $125-$ 133; ZAŤKO, Peter - TEREN, Štefan. Národohospodár Peter Zatko spomína. Liptovský Mikuláš: Tranoscius, 1994, s. 26-29. ISBN 807140036.

63 Karel Teige v roce 1936 odsoudil moskevské procesy a poté opakovaně vystupoval proti schematickému umění, čímž se dostával do rozporu s principy komunistické kulturní politiky. Po únoru 1948 se ocitl v izolaci a byl stranickými ideology obviňován z trockismu a buržoaz- 
nacionalizmus a kozmopolitizmus sú bližence, [...] dve stránky tej istej veci“. Vzápětí se vypořádal s přežívající teorií, podle níž „,Novomeský a jeho spolupracovníci v DAVe skĺzli falošným smerom najprvv literatúre a až potom [...] v politike“. Bylo to přesně naopak, nebot' „prvenstvo tu malo ideologické, politické zameranie, cudzie, nepriatel'ské socialistickej ideológii “, které se v literární práci projevovalo buržoazní úpadkovostí.

Od kategorických soudů nad davisty přešel Šefránek k adresné kritice Novomeského názorů a literárního díla. Prohlásil, že jeho „,poézia nikdy nebola socialistická “, aniž by však tento svůj výrok dále rozvedl. Odkázav na Leninovu práci Dětská nemoc levičáctví v komunismu sice připustil, že básník se na rozdíl od svých souputníků nikdy nedopouštěl ,malomeštiackeho anarchizmu a radikalizmu“, ale v ,jeho básnických zbierkach niet ani jediného socialistického riadka “, a to ani ve dvacátých letech, kdy „DAV ešte celkove budil falošný ,revolučny' dojem ". Novomeského poezie se pouze kryla socialistickými frázemi a objektivně vyjadřovala zájmy buržoazie, mimo jiné proto, že její autor odmítal tendenčnost v uměleckém díle. ${ }^{64}$

Dále Šefránek tepal Novomeského pohledy na sovětskou literaturu a kulturu všeobecně. Podle jeho úsudku bývalý pověřenec školství ,,dlhé roky sympatizoval s trockizmom “, ,ignoroval klasiky marxizmu-leninizmu“ a pozitivně hodnotil literární názory Karla Radka a Nikolaje Bucharina, a to ještě v době, kdy se oba jako „kontrarevolucionári, záškodníci a špióni“ ocitli před soudem. Na sovětskou literaturu se díval přezíravě, uznával z ní jedině Sergeje Jesenina a Borise Pasternaka, které vzal na milost jen pro jejich , malomeštiacky anarchizmus, resp. formalizmus".

V souvislosti s tím šéf ,agitpropu“ dezinterpretoval smysl Novomeského vystoupení na kongresu slovenských spisovatelů roku 1936, týkajícího se vztahů idejí a kultury evropského Západu a Východu. Básníkovi předhodil, že pod vlivem bucharinovské poučky o poklidném vrůstání kapitalistických živlů do so-

ního kosmopolitismu. Ostré kritice jej roku 1950 podrobil Ladislav Štoll v pamfletu Třicet let bojů za českou socialistickou poezii. Praha: Orbis, 1950, s. 60-63, 85-88. Agresivní kampaní usmýkaný Teige podlehl v ř́ijnu 1951 srdečnímu infarktu.

64 Šefránek tvrdil, že už básníkův debut Nedel'a (1927) neměl socialistický ráz, nebot' „,niekol'ko sentimentálnych , sociálnych 'obrázkov nemožno zamieňat' so socialistickou poéziou “. Místo socialistických ideálů Novomeského zajímaly „bohémske, pijanské a erotické scény $v$ nočných lokáloch parížskeho podsvetia“. Navazující sbírky Romboid (1932) a Otvorené okná (1935) zaběhly „,do artizmu a poetizmu, tohto predchodcu surrealizmu“. Jako politický básník se Novomeský poprvé ozval v knížce Svätý za dedinou (1939), ale jen proto, aby dal „,básnický výraz clivote, úzkosti, osamelosti, porazenectvu“ - tedy ,,kapitulácii pred fašistickým nepriatel'om “. A deset básní z let 1940-1941, které vydal už jako pověřenec pod názvem Pašovanou ceruzkou (1948), jen podtrhlo ,,beznádejnost’ a zúfalstvo toho istého politického postoja“. 
cialismu, rozvinul „podobnú teóriu o miernom splynutí kapitalistickej kultúry Západu so socialistickou kultúrou Východu, tj. Sovietskeho zväzu“. Odsoudil Novomeského výrok, který za největší událost současných evropských dějin označil ,zbližovanie a splývanie idei a kultúr Západu a Východu“, i jeho představu, že tento ,proces vraj povedie $k$ syntéze kultivovanosti Západu a všeludských túžob Východu“. Za situace trvajícího tř́́dního boje označil tyto náhledy za iluzorní, nebot' splývání kapitalistické a socialistické kultury může být podmíněno jen smířením obou systémů, které z principu není možné. ${ }^{65} \mathrm{~A}$ připomněl, že Novomeského prognózy byly předobrazem jeho poválečné ,, buržoázno-nacionalistickej teórie " o tom, jak ,, v oslobodenej republike nebude prebiehat' triedny boj, [...] buržoázia zmúdrela a [...] týmto podmienkam treba prispôsobit’ aj politiku, [...] ktorá pomáha buržoázii na koňa proti l’udovej demokracii, proti socializmu" ${ }^{66}$

Výše uvedené postuláty Šefránek završil zevšeobecňujícím konstatováním, že „,Novomeský a DAV má vel'kú vinu na tom, že sa moderná slovenská literatúra zamorila formalizmom, artizmom, bezideovost'ou, naturalizmom, buržoáznym nacionalizmom a kozmopolitizmom. "Slovenští spisovatelé musí s těmito jevy neúnavně zápasit, jelikož ,škodlivé následky“ jejich působení v literatuře ještě nejsou ani zdaleka překonány. ${ }^{67}$

Aby tomuto boji dodal na pádnosti, navázal na Reimanova a Lajčiakova obvinění a nesmlouvavě odsoudil prozaická a literárně kritická díla Mináče, Tatarky, Chorvátha a Matušky, k nimž nově přidal také práce strukturalistického teoretika Mikuláše Bakoše. ${ }^{68}$ Nakonec spisovatele vyzval, aby přehodnotili literární minulost a přestali se ,opičit’ po podenkových hviezdach upadajúcej a hnijúcej buržoáznej literatúry", navázali na domácí realistické tradice, brali si př́klad

65 Na spisovatelském kongresu, kde se poprvé společně sešli autoři různorodého uměleckého i politického přesvědčení, vystoupil Novomeský s kritikou provinčnosti slovenské kultury a současně zdůraznil potřebu jejích kontaktů se světovým děním na Východě i Západě. Východiskem (nejen slovenského) kulturního snažení (a všeobecného pokroku) mělo být střetávání humanistického odkazu západní tvorby a komunistických myšlenek, které se prosadily na Východě. Slovenská kultura z toho syntetizujícího procesu musí čerpat a zároveň se na něm podílet, nebot' jen tato syntéza dokáže postavit hráz proti barbarství a výbojům nekulturnosti, ,,nech si dáva[jú] meno ,vrúceho nacionalizmu', ,rasovej nadradenosti ', ,církevno-náboženskej samospasitel’nosti alebo priamo - ,fašizmu!" CHMEL, Rudolf (ed.). Kongres slovenských spisovatel'ov 1936. Bratislava: Tatran, 1986, s. 38-50, 189-192.

66 Vedoucí ,agitpropu“ zde narážel na teze Novomeského sebekritiky na zasedání ÚV KSS v dubnu 1950. SNA, f. KSS-ÚV, k. 1823, plénum ÚV KSS, 6. - 7. 4. 1950, stenografický záznam, s. 43-56.

67 Všechny citáty o Novomeském a ostatních davistech vycházejí z brožury ŠEFRÁNEK, Július. Niektoré ideologické problémy našej literatúry. Bratislava: Slovenský spisovatel', 1951, s. 9-26.

68 ŠEFRÁNEK, ref. 67, s. 48-49. 
z českého i sovětského písemnictví a přimkli se $\mathrm{k}$ dělnické tř́dě a komunistické straně. ${ }^{69}$

Podle oficiální zprávy uveřejněné v tisku přijal spisovatelský aktiv Šefránkovo vystoupení s nadšením. ${ }^{70} \mathrm{~V}$ následující rozpravě vystoupilo třicet šest účastníků s kritickými a sebekritickými příspěvky, jejichž výběr poté Kultúrny život několik týdnů uveřejňoval. ${ }^{71}$ Realita ale byla značně odlišná. Diskusi silně poznamenala atmosféra strachu rámovaná mučivou nejistotou, jak se v dané situaci zachovat, a vyhrocenou útočností, kterou se kritici snažili vyhnout tomu, aby se sami stali objekty ataků stranické věrchušky. Symptomatické také bylo, že naprostá většina literátů primárně nenapadala pozatýkané davisty, ale obviněnou pětici svých spisovatelských kolegů. ${ }^{72} \mathrm{~S}$ Novomeským si obsáhleji vyřizovali účty pouze Andrej Plávka, ${ }^{73}$ navíc velmi obecně, a Ján Rozner, který rozhorleně odsoudil způsob, jakým básník referoval o průběhu moskevského sjezdu sovětských spisovatelů v roce $1934 .{ }^{74}$ Přesto se na stránkách spisovatelského týdeníku postupně objevily další přehodnocující články, které rozvíjely Šefránkủv referát a v nichž na Novomeského hlavu pršely další výpady. ${ }^{75}$

S vyzněním diskuse na aktivu spisovatelů komunistů byli pracovníci kulturně-propagačního oddělení ÚV KSS značně nespokojeni. Július Šefránek tudíž 10. května 1951 předložil stranickému sekretariátu návrh na svolání plenární schůze Slovenské sekce SČSS, po níž se bezprostředně mělo sejít i její valné shromáždění, které by zvolilo nové svazové vedení. ${ }^{76}$ Záměry moci vzápětí od-

69 ŠEFRÁNEK, ref. 67, s. 49-53. K Šefránkovu projevu srovnej DRUG, Kapitoly, ref. 58, s. 233-236; DRUG, ref. 46, s. 112-114; PETRÍK, ref. 27, s. 77-80; BÍLIK, ref. 27, s. 28.

70 Aktív slovenských spisovatel'ov - komunistov. In Kultúrny život, 1951, roč. 6, č. 14, s. 1.

71 Kultúrny život, 1951, roč. 6, č. 16-18, s. 3-4.

72 Průběh debaty výstižně charakterizoval Vladimír Petrík jako ,zmes úprimnosti, naivity a pokrytectva“", v níž se mísí ,, sebazničujúce obviňovania so zlomysel’nými [a konjunkturálnymi] invektivami“. [...] A pritom len v nepatrnej miere išlo o odhalenie nejakých ,buržoáznonacionalistických', či ,kozmopolitných ' názorov (pretože nikto presne nevedel, kde sa majú hl'adat'), všetko sa vybíjalo v pseudomoralizovaní. [...] Aktiv stmelil proti kritizovaným všetkých spisovatel'ov, bez ohl'adu na to, či išlo o prívržencov socialistického realizmu, ruralistov či lyrizujúcich prozaikov, marxistov alebo katolikov. Všetci sa usilovali o jedno: Ukázat', ako nesmierne ideovo prerástli kritizovaných autorov. A pretože to nebola pravda, [...] vyzneli vystúpenia na aktíve napospol len ako nepodarené divadlo, zinscenované na zastrašenie všetkých. " PETRÍK, ref. 27, s. 80-81.

73 S režimem konformní Plávka aktiv později reflektoval ve svých normalizačních pamětech. O vlastním vystoupení se však nezmínil ani slovem. PLÁVKA, Andrej. Plná čaša: Diel druhý Smädného milenca. 2. vydání. Bratislava: Slovenský spisovatel', 1979, s. 93.

74 Kultúrny život, 1951, roč. 6, č. 16, s. 3-4.

75 CHOMA, Branislav. Prekonat' buržoázne vplyvy v našej literatúre. In tamtéž, č. 16, s. 1-6; BENDOVÁ, Krista. Proti zvyškom buržoáznej ideológie v literatúre. In tamtéž, č. 18, s. 1.

76 SNA, f. KSS-ÚV, sekretariát ÚV KSS, k. 18, 18. schůze, 10. 5. 1951, b. 3, Návrh na plenárne a valné zhromaždenie Národnej sekcie zväzu čs. spisovatel'ov. Podkladový materiál hodnotil 
halil nepodepsaný úvodník Kultúrneho života, jenž zdůraznil mimořádný význam připravované akce, protože na ní „pôjde o ešte širšie odhalenie vplyvu zradcov a špiónov Clementisa a Novomeského na vývin [literatúry] “, než jaké představil Šefránkův proslov na sklonku března. A také velmi plasticky objasnil motivy jejího konání. Prezentovaná analýza literárního vývoje po roce 1918 zastihla mnohé spisovatele teoreticky a ideologicky nepřipravené hledat škodlivé jevy v jeho průběhu. Následná diskuse , sa nesústredila [...] na to hlavné - na rozdrvenie buržoázneho nacionalizmu a kozmopolitizmu“, kterými davisté zaplevelili slovenskou literaturu. Někteř́ tvůrci nepochopili, že ,,je rozdiel medzi [...] odsúdením Clementisa a Novomeského a medzi bol'ševickou kritikou, ktorá má pomôct' kritizovaným literárnym pracovníkom prekonat' vplyv DAVu a prebijat' cestu vpred". Plenární schůze proto musí při rozboru neblahého odkazu davistů (včetně Daniela Okáliho a Jána Poničana) jít více do hloubky a soustředit se především na fakt, že „Novomeský pripravil pôdu pre rozbujnenie úpadkovej surrealistickej poézie, ktorej básnici podl'ahli jeho vplyvu viac ako vtedy sami spoznali a pochopili. " "77 Přednesením rozšířené kritiky byl stranickým sekretariátem pověřen spisovatel a pracovník kulturně-propagačního oddělení ÚV KSS J. Špitzer, jenž již nějaký čas plnil roli prostředníka mezi partajním aparátem a uměleckými organizacemi, pravidelně tlumočícího právě schválenou kulturně-politickou linii.

Bývalý partyzán a př́vrženec avantgardních slovenských básníků i výtvarníků se nezhostil podobného úkolu poprvé. ${ }^{78} \mathrm{Na}$ pokyn vyšších míst vystou-

rozpravu na březnovém aktivu záporně, jelikož kritika a sebekritika sklouzla do osobní roviny a nesoustředila se na literární analýzu konkrétních děl. Pominula zhoubný vliv davistů, zvláště Clementise a Novomeského, na literární vývoj po skončení války. Tamtéž, b. 5, Niektoré otázky slovenskej literatúry.

77 Smelšie rozvinút' boj proti buržoáznym nacionalistom a kozmopolitom. In Kultúrny život, 1951, roč. 6, č. 19, s. 1.

78 Špitzer prošel na přelomu čtyřicátých a padesátých let turbulentním vývojem. Po únoru 1948 byl šéfredaktorem odbojářského týdeníku Bojovnik, do nějž mj. psal literární, divadelní a výtvarné recenze, $v$ nichž se pochvalně vyjadřoval o moderním umění domácí i zahraniční provenience. Věřil v možnost jeho koexistence s komunistickou ideologií. Navštívil Paříž a v lednu 1949 se podílel na organizaci bratislavské výstavy španělského kubistického a surrealistického malíře Óscara Domíngeze. Stal se tajemníkem Kulturní komise ÚV KSS, kterou řídil Novomeský. Patrně z přesvědčení se v roce 1949 přiklonil k podpoře socialistického realismu a na popud M. Chorvátha odešel pracovat na kulturně-propagační oddělení ÚV KSS, kde se zúčastnil kampaní proti straně nepohodlným umělcům (Leopold Lahola, Emil Boleslav Lukáč). Přesto ještě v létě 1949, nejspíš inspirován Novomeským, začal připravovat reprezentativní sborník k 25. výročí vzniku $D A V u$, který po kritice tzv. buržoazního nacionalismu už nespatřil světlo světa. Srovnej ŠPITZER, Juraj. V̌̌edné dni, sv. 1. Ed. Štefan Drug. Bratislava: Vydavatel'stvo Ivana Štefánika, 2001, s. 9-11. ISBN 8096918921; PEŠEK, Jan et al. Aktéri jednej éry na Slovensku 1948 - 1989. Prešov: Vydavatel'stvo Michala Vaška, 2003, s. 331332. ISBN 8071654175. 
pil veřejně proti davistům již v květnu $1950 .{ }^{79}$ Po roce své postřehy zopakoval a dále rozvinul. Opíraje se o Širokého projevy, utilitárně zvolené citáty z dobového tisku, osobní korespondenci či úryvky z různých básní přednesl delší a podstatně dramatičtější variaci Šefránkova referátu, v níž nekompromisně odsoudil Novomeského poezii i jeho publicistické názory na literární tvorbu. Určitou obsahovou nesourodost své ,vědecké" analýzy vyvažoval osobním zápalem, výrazovou expresivitou, sugestivním a patetickým stylem. Zjitřené emoce měly zakrýt mnohočetná překrucování faktů, která $\mathrm{v}$ duchu poválečných ždanovovských kampaní získala zcela novou interpretaci.

Podobně jako jeho nadřízený se Špitzer nejprve ostře vypořádal s celou davistickou skupinou. Podle něho sympatizovala $\mathrm{s}$ trockismem a stála $\mathrm{v}$ opozici proti realistické orientaci slovenské literatury, kterou reprezentovali Petr Jilemnický a Eduard Urx spolupracující s českými marxisty (Julius Fučík, Zdeněk Nejedlý, Stanislav Kostka Neumann, Bedřich Václavek, Jiř́ Wolker). Vrcholné představitele $D A V u$ přirovnal k řadě , kapitulantov a zradcov" mezi pokrokovými tvůrci, za něž označil ve Francii André Gida, André Bretona či Salvadora Dalího a v Čechách Karla Teigeho a Záviše Kalandru. Proti nim opětovně vyzdvihl P. Jilemnického jako průkopníka socialistického realismu. Jeho tř́ídně uvědomělé nazírání na povahu spisovatelské práce stavěl do př́krého kontrastu s „nemarxistickými““ a „kosmopolitními“ stanovisky Novomeského. ${ }^{80} \mathrm{Z}$ nich věnoval zvláštní pozornost básníkově publicistické reflexi moskevského sjezdu sovětských spisovatelů na podzim 1934. Vytkl mu, že ve svých článcích odmítal podřízenost literární tvorby potřebám třídního zápasu a místo toho upřednostňoval uměleckou hodnotu před tendenčností ( $\mathrm{tj}$. poplatností aktuálním ideologickým schématům). Pomíjel názory Maxima Gorkého, přešel Stalinův apel, aby spisovatel „,bol inžinierom l'udských duši “, ignoroval Ždanovovy požadavky, aby se literáti stali „organizátormi pretvárania povedomia l’udí v duchu socializmu“, kteří se ocitnou „,na predsunutých pozíciách bojovníkov za beztriednu

79 V projevu podrobil kritice tvorbu davistů a nadrealistů, kteří měli podlehnout vlivům francouzského moderního umění. Napadal především Novomeského, byt' ho otevřeně nejmenoval. K niektorým otázkam našej literatúry - Ohňom sebekritiky k novej tvorbe v duchu socialistického realizmu! In Kultúrny život, 1950, roč. 5, č. 9, s. 3.

80 Po vzoru Gosiorovského $\mathrm{k}$ tomu využíval účelově vytrhané citáty z Jilemnického dopisů E. Urxovi z let 1925 - 1928. Jejich prostřednictvím se snažil „,dokázat“, že Jilemnický si již tehdy všiml Novomeského nepevného vztahu k proletariátu i jeho záliby ve formalistických experimentech. Zároveň zveličil Jilemnického názorové rozpory s ostatními davisty. ŠPITZER, Juraj. Proti buržoáznemu nacionalizmu a kozmopolitizmu - za vyššiu ideovost'slovenskej literatúry. Bratislava: Slovenský spisovatel', 1951, s. 25-26, 38-45. Realita byla pochopitelně značně odlišná. Srov. úplné znění spisovatelovy korespondence in ROSENBAUM, Karol (ed.). Listy Petra Jilemnického, sv. I (1917-1936). Bratislava: Pravda, 1984, s. 198-201, 249-251, 294-301. 
spoločnost'“. Na místo toho se hlásil k Bucharinovu referátu a po něm opakoval: „,Tendencia až za kvalitou, na miesto druhé, kvalitu a len kvalitu. “ A sám k tomu dodával: , Úzky rámec funkcie literatúry byt' vždy a vždy len každodenne revolučnou, bol príliš jednostranný. " Manifestoval dále svůj kosmopolitismus tvrzením, že „,proletárska literatúra musí ešte na meštiacku nadväzovat", nebot’ „,napr. celá moderná literatúra vyrástla od Apolinaira “ ${ }^{81}$ Špitzer z toho vyvodil závěr, že básník se tehdy projevil jako ,dohadzovač neuskutočnitelného sobáša socialistickej literatúry s úpadkovou literatúrou zahnívajúcej buržoázie“. Nazval ho „dobrým žiakom Bucharina“ a pašerákem ,kozmopolitických tendencii “, který v tisku zesměšňoval sovětskou literaturu. ${ }^{82}$ Zdrojem tvůrčí inspirace se mu nikdy nestala Moskva a ,heroizmus sovietskeho života, ale Pariž [...] André Gidea ", do které společně s Teigem zavlekl české a slovenské básníky, aniž by dbal varování Neumanna, Wolkera a Jilemnického. ${ }^{83}$ A o pár stránek dále se s básníkovými myšlenkami o literatuře definitivně vypořádal: „Poklonkovanie západnému dekadentnému umeniu a nenávist' proti socialistickému realizmu, to je literárna línia Novomeského. "84

Velmi ostrým soudům podrobil Špitzer také Novomeského poezii. Básník propadl kosmopolitismu již od počátku své tvorby ve dvacátých letech, kdy začal tvořit „,poéziu kaviarní, barov [a] nevestincov“ a „,motýl"“ jeho básnění ,,splodil červa dekadencie - surrealizmus, $v$ ktorom dominuje melanchólia, elégia, strašidelná vízia a bezútešné situácie ". ${ }^{55}$ Postupně komentoval vybrané verše z jednotlivých sbírek, až dospěl k básni Aký si z , kapitulantskej zbierky Svätý za

81 ŠPITZER, ref. 80, s. 19-21. Autor polemizoval s Novomeského výroky z časopiseckého rozhovoru, jejichž vyznění hrubě zkreslil. Viz S Lacom Novomeským o zjazde spisovatel'ov Soviet. zväzu. In Šíp, 1934/1935, roč. 2, č. 1, s. 9-11. Svou argumentaci založil na kritice básníkovy teze o tom, že ,, literatúra nesmie byt každodennou slúžkou triedneho boja “, od níž odvíjel další odsudky.

82 ŠPITZER, ref. 80, s. 35-37. Zde si Špitzer vzal na paškál Novomeského postřeh z článku Sovětská literatura a sovětská veřejnost konstatující, že , tvrdost’ a suchost'stala sa dokonca určitým rysom úrovne sovietskej literárnej tvorby“. Odsoudil také jeho liberální interpretaci socialistického realismu převzatou od Bucharina, do níž ,, možno umiestit’ všetky avantgardné moderné literárne a umelecké snahy, ktoré vznikali a vyrastali z odporu proti tomu realizmu, ktorý poznáme z histórie meštiackej literatúry minulých storoči “. Dále pranýřoval básníkovy citáty z projevu Karla Radka na moskevském kongresu spisovatelů. Novomeského článek byl otištěn v Teigeho revue Doba, 1934, roč. 1, č. 11-12, s. 162-174; citováno podle NOVOMESKÝ, Ladislav. Manifesty a protesty. Bratislava: Epocha, 1970, s. 179 a 188.

83 Na tomto místě se Špitzer opřel o Štollovy argumenty, ref. 63, s. 85-88.

84 ŠPITZER, ref. 80, s. 54.

85 ŠPITZER, ref. 80, s. 21-23. Pracovník stranického agitpropu rovněž básníka napadl za to, že básnickou sbírku Romboid věnoval ,zaviatej pamiatke Janka Král’a“. Dopustil se tím de facto svatokrádeže a urazil tak všechny vlastenecké básníky. Hř́šně se proto mýlí literární kritici, když tvrdí, že vývoj slovenské poezie směřuje od romantika Král'a přes Novomeského $\mathrm{k}$ nadrealismu. 
dedinou “, kterou označil za Novomeského „,autocharakteristiku“ a ukázku ryzího kosmopolitizmu zveršovaného ,,beznárodným cynickým svetobežníkom “" ${ }^{86}$ A poté nad básníkem vynesl jednoznačný ortel: „Nevera $v$ robotnícku triedu, nevera v Sovietsky zväz, povýšenecký pomer $k$ vlastnému l'udu, chuligánstvo a bohémstvo, beznárodný kozmopolitizmus, estetizovanie nizkosti včloveku, to je Novomeského poézia. "87

Stranou kritiky nezůstalo ani Novomeského „závadné“ chování za Slovenského státu, kdy nepřestal vystupovat jako „patrón dekadencie a bezideového formalizmu“, který si hrál na revolucionáře v prostředí ,, kolaborantských a fašistických básnikov". Svým individualismem nakazil mnohé slovenské spisovatele a skrze surrealismus „vrážal nôž do srdca pokrokovým úsiliam slovenskej literatúry " ${ }^{88}$ Četnými kontakty s Machem a literární elitou lud'áckého režimu ukazoval začínajícím tvůrcům způsob, jak se smiřovat s fašismem: „Hanebnost' Novomeského $v$ tomto období spočiva $v$ tom, že mladí básnici videli v ňom socialistického básnika, videli v ňom svoj vzor, počúvali jeho hlas - a tento hlas ich orientoval do kozmopolitických vôd nezrozumitel'ného surrealizmu, viedol ich predstieraním odporu voči fašizmu [...] k legálnemu literárnemu spolunaživaniu. “ Ještě po válce se Novomeský vracel ke svým zhoubným názorům z trenčianskoteplického kongresu spisovatelů z roku 1936 a přimlouval se za to, aby ráz slovenského kulturního života byl syntézou progresivních impulsů z Východu i Západu. ${ }^{89}$ Společně s ostatními davisty bránil „,svojím prehnitým

86 Podle Špitzera se bývalý pověřenec školství takto ptal sám sebe a hned si dával odpověd': „,...emigrant bez vlasti a všade s domovom, / rebrinák bez záprahu na pokraji cesty, / alebo jarným bleskom rozčesnutý strom, / tá smutná hruška v poli s nalomenou šijou, / udalost' neschválna, a predsa bez náhod, / cynický svetobežnik s tajnou nostalgiou, / večný Žid na pobreži babylonských vôd“. ŠPITZER, ref. 80, s. 24-25. V šedesátých letech vyšlo ze svědectví Lídy Clementisové i samotného Novomeského najevo, že tato báseň z roku 1939 byla ve skutečnosti věnována Clementisovi. Reflektovala politikův odchod do emigrace po vzniku Slovenského státu i jeho obtížné postavení uvnitř KSČ. HOLOTÍKOVÁ, Ladislav Novomes$k y ́$, ref. 62, s. 304.

87 ŠPITZER, ref. 80 , s. 25.

88 ŠPITZER, ref. 80, s. 54-55. Proti němu vysoce vyzdvihl antifašistickou poezii Janka Jesenského.

89 ŠPITZER, ref. 80, s. 67-68. Špitzer odsuzoval Novomeského projev na I. sjezdu slovenských umělců a vědeckých pracovníků v Banské Bystrici z 27. srpna 1945. Pověřenec školství, reflektující konec války, orientaci československé zahraniční politiky na Sovětský svaz i své komunistické přesvědčení, v něm mj. řekl: „, I ked' vidime dilemu Západu a Východu riešenú rozhodným priklonom nášho kultúrneho života k slovanskej kultúre, menovite ku kultúre východných Slovanov, [...] pri tomto našom dejinnom rozhodnutí upevňovat' budeme zväzky so západným kultúrnymi žriedlami. [...] Na križovatke takto vyznačenej uvedomujeme si vel'mi jasne, že ked’ aj plnou vol’ou nášho národného a kultúrneho bytia prináležíme $k$ Výcho$d u$, tvar $i$ vývin nie jednej významnej umeleckej discipliny a vynikajúceho kultúrneho zjavu $u$ nás bol podmienený príbuzenstvom $k$ duchovnému a kultúrnemu ruchu západnému, preto 
liberalizmom a bezideovým postojom " tomu, aby generačně mladší autoři našli místo „,po boku robotníckej triedy, v bezvýhradnej oddanosti ku komunistickej strane a Sovietskemu zväzu".90

Vedle Novomeského se Špitzer př́křre vymezil i vůči uměleckým názorům a tvorbě D. Okáliho, J. Poničana a E. B. Lukáče, který však do davistické skupiny ani nepatřil. Neopominul také pětici kritizovaných spisovatelů (Bakoš, Chorváth, Matuška, Mináč, Tatarka). Uvedl sice, že nedostatky literární činnosti těchto autorů „treba vidiet' [...] v priamej súvislosti s tými teóriami, ktoré davisti [...] a najmä Novomeský [...] udomácňovali v našej literatúre", ale jejich kritiku, s výjimkou Bakoše, dále neprohluboval a také ji nepřeváděl do politické roviny. Omezil se pouze na pranýřování ideových a literárních nedostatků v jejich díle. ${ }^{91} \mathrm{Z}$ toho se dalo usuzovat, že kampaň proti tzv. buržoaznímu nacionalismu ve spisovatelských řadách již neporoste do šíre a nadále se soustředí jen na pokračující ostrakizaci hlavních reprezentantů $D A V u .{ }^{92}$ Navzdory tomu však bývalý partyzán a pracovník agitpropu ÚV KSS zakončil svůj projev bojovnou výzvou: ,,Vd’aka našej strane - spolu s odhalením protištátnej činnosti Clementisa a spol. - je porazená na hlavu aj ideológia, ktorú davisti Clementis, Novomeský a Husák hlásali. Treba železnou metlou vymiest'všetko dedičstvo, čo po nich zostalo, všetky falošné názory, ktoré stavajú múr medzi pracujúcich rúk a ducha, či ich stvorila zlá vôl'a alebo nevedomost'. "93

Ve své stati se Špitzer inspiroval sovětskými kampaněmi proti avantgardním umělcům i stalinskými monstrprocesy třicátých let (citoval mj. i prokurátora Andreje Vyšinského). Jejím prostřednictvím vytvořil zcela zdeformované hodnocení dějin moderní slovenské literatury, v němž se kladného hodnocení dostalo pouze marxistům Jilemnickému, Urxovi a Fraňo Královi a nekomunistovi Jesenskému, zatímco literární avantgarda byla zatracena. ${ }^{94}$ Jeho expresivní proslov

tiež nechápeme jednoznačnost' našej kultúrnej orientácie ako jednostrannost' a náš d'alši vývoj je otvorený oplodňujúcim vplyvom s ktorejkol'vek strany. [...] Smelo sa prihovárame za to, aby pri novom rozmachu [...] vztahov [...] k východoslovanskému svetu, uchovali a utužovali sa aj styky našej kultúry, najmä umenia zo Západom, lebo nás skúsenost' naučila, že tieto kategórie vonkoncom nestoja proti sebe. "MRLIAN, Rudolf (ed.). Sbornik z I. sjazdu umelcov a vedeckých pracovníkov 27. a 28. augusta 1945 v Banskej Bystrici. Bratislava: Umelecká a vedecká rada a Povereníctvo informácií, 1946, s. 75-76.

90 ŠPITZER, ref. 80, s. 80.

91 ŠPITZER, ref. 80, s. 80-85.

92 Jistou zdrženlivost ve směřování kampaně lze odvodit také z toho, že v tisku se Špitzerův referát objevil s měsíčním zpožděním. Kultúrny život, 1951, roč. 6, č. 25, s. 1, 4-5; č. 26, s. 5; č. 27, s. 3-4; Nové slovo, 1951, roč. 8, č. 24, s. 466-468; č. 25, 492-493; č. 26, 511-513.

93 ŠPITZER, ref. 80, s. 86.

94 Z literatury se k Špitzerovu projevu obsáhleji vraceli DRUG, Kapitoly, ref. 58, s. 221-224; DRUG, ref. 27, s. 34-35; PETRÍK, Vladimír. Hladanie minulého času. Bratislava: Slovart, 2009, s. 98-99. ISBN 9788080857851; PETRÍK, ref. 27, s. 81-82. 
představoval pomyslný vrchol diskreditačního tažení proti Novomeskému, nikoliv však jeho konec. Těžko dnes rozsoudit, jaké faktory nejvíce ovlivnily finální podobu Špitzerova textu. Zda autorova osobní iniciativa a přesvědčení, možný strach z represí, manipulativní přemlouvání a rozkazy nadřízených stranických funkcionářů, nebo setrvalý nátlak z pražského centra.

Po vzoru spisovatelů se do boje proti tzv. buržoaznímu nacionalismu, kosmopolitismu a formalismu svými schůzemi postupně zapojovaly také ostatní umělecké svazy. V dusné atmosfére kritiky a sebekritiky byl i na nich Novomeský občas napadán. Jednotlivé útoky však originalitou př́liš nevynikaly, více méně vycházely z již publikovaných projevů stranických funkcionářu. Těžko tomu mohlo být jinak, nebot' hudba, divadlo a výtvarné umění nebyly sférami básníkovy umělecké aktivity, byt' se o ně jako novináŕ dlouhodobě zajímal, mezi jejich protagonisty měl řadu prátel a po roce 1945 jako pověrenec školství a osvěty stimuloval jejich rozvoj. Přesto na aktivu výtvarníků komunistů 18 . května 1951 sochař Rudolf Uher Novomeského odsuzoval za propagaci formalismu a cílené odvádění umělců od lidu i socialistické výstavby ${ }^{95} \mathrm{O}$ pár týdnů později charakterizoval dramatik Peter Karvaš na zasedání Slovenské sekce Divadelní a dramaturgické rady básníkovo působení v čele pověřenectva jako dobu „úchylnej, slovenskému umeniu nepriatel'skej kultúrnej politiky “.96 Hudebníci také vícekrát proklamovali svou loajalitu stranické linii, adresným útokům se ale zřejmě vyhnuli. ${ }^{97}$

Na základě rozhodnutí sekretariátu ÚV KSS z 23. března 1951, o kterém jsme se již zmínili, byla v tisku proti jednotlivým tzv. buržoazním nacionalistům rozpoutána rozsáhlá diskreditační kampaň, do níž se z přesvědčení či pod nátlakem zapojily desítky stranických funkcionáŕů a intelektuálů..$^{98} \mathrm{~V}$ př́padě Novomeského se snažila očernit téměř všechny aspekty jeho veřejného působení. Velký prostor pochopitelně věnovala básníkovým aktivitám na poli literatury a kultury. Publikované články většinou vycházely ze Šefránkových a později i Špitzerových postulátů, které dále doplňovaly o nové detaily. Z novinářù projevil výraznou iniciativu už několikrát uvedený Ján Rozner, jehož první př́spěvek v Pravdě dokonce posloužil jako zásadní zdroj inspirace pro Šefránkův referát. ${ }^{99}$ Také

95 Za socialistický realizmus vo výtvarnom umení. In Kultúrny život, 1951, roč. 6, č. 22, s. 1 a 3.

96 O budování slovenského divadla. In Kultúrny život, 1951, roč. 6, č. 29, s. 1. Dopad tzv. buržoazního nacionalismu na divadelnictví analyzoval ještě Rozner. Viz Obdobie úpadku slovenskej drámy a vplyv buržoázneho nacionalizmu. In Nové slovo, 1951, roč. 8, č. 28, s. 551-553.

97 K širšímu kontextu GREŠÍK, Ladislav. Slovenská kultúra v začiatkoch budovania socializmu (1948 - 1955). Bratislava: Pravda, 1980, s. 246-254; DRUG, ref. 27, s. 32-33.

98 O dva měsíce později stranické orgány obsah kampaně dále upřesňovaly. SNA, f. KSS-ÚV, sekretariát ÚV KSS, k. 18, 20. schůze, 26. 5. 1951, b. 21, Propagačná kampaň vo vede po zasadnutí ÚV KSS.

99 Prekonat' vplyv buržoázneho nacionalizmu v oblasti kultúry. In Pravda, 1951, roč. 32, č. 68, 
Roznerovy následující statě se vyznačovaly mimořádně ostrým tónem. ${ }^{100} \mathrm{~V}$ insinuacích si rovněž smočili pero kulturní redaktor Pravdy Branislav Choma, který se vypořádal především s Novomeského poválečnými kulturně-politickými názory, ${ }^{101}$ a básník Vladimír Reisel, odsuzující bývalého pověřence jako patrona avantgardních uměleckých směrů. ${ }^{102}$ Vícero textů ještě utilitárně velebilo odkaz Jilemnického. ${ }^{103}$

Značná pozornost se koncentrovala na kritiku Novomeského působení v čele školského resortu. Jednotliví pisatelé (Gustáv Pavlovič, Ernest Sýkora, Ludovít Bakoš, Ján Kotoč) bývalému pověřenci předhazovali, že svým ideovým kompromisnictvím vnášel do vzdělávací soustavy nadstranického ducha a „buržoazní objektivismus“. ${ }^{104} \mathrm{Za}$ pomoci „usvědčujících“ citátů z jeho veřejných proslovů mu vyčítali dlouhou sérii hř́́chů: Při výstavbě školství kladl prioritní důraz na jeho organizační a kvantitativní rozvoj, nezajímal se o reálný obsah výuky, v důsledku čehož školní výchova dosud nebyla podřízena principům marxismu-leninismu. Při formulování výchovně-vzdělávacích cílů si vypomáhal výroky štúrovců a buržoazních politiků (Masaryk, Beneš), aniž by zmínil názory Marxe, Engelse, Lenina a Stalina. ${ }^{105}$ Na pověřenectvu školství ponechával úřednictvo z éry Slovenského státu. Smírrlivou kádrovou politikou chránil reakční učitele. Nezajistil

s. 6-7.

100 O niektorých otázkách jazyka v literatúre. In Kultúrny život, 1951, roč. 6, č. 23, s. 4-5; Boj o českú socialistickú poéziu. In Kultúrny život, 1951, roč. 6, č. 28, s. 5. Ve druhém příspěvku Rozner aplikoval Štollův elaborát Třicet let boju za českou socialistickou poezii na vývoj slovenského básnictví. Nabízí se otázka, proč Roznerovy texty, z hlediska charakteru útoků na Novomeského téměř srovnatelné se statěmi Šefránka a Špitzera, nezískaly takovou váhu a ,proslulost“. Patrně proto, že Rozner byl nestraníkem, jeho články se neprezentovaly jako partajní direktivy a nevyšly v samostatné brožuře.

101 Prekonat' buržoázne vplyvy v našej literatúre. In Kultúrny život, 1951, roč. 6, č. 16, s. 1 a 6. Choma později uváděl, že své odsuzující články psal na pokyn vyšších míst i z přesvědčení. Později se za to Novomeskému omluvil. CHOMA, Branislav. Moja pút' socializmom. In Slovo: Almanach vedeckých úvah a umeleckých aktivit, 1998, roč. 4, č. 1, s. 88, 90. ISSN 13351540 .

102 Agentúra imperializmu v umení. In Kultúrny život, 1951, roč. 6, č. 36, s. 3. Reisel byl přitom významným představitelem slovenského nadrealismu. Krátce po osvobození vydal první monografii o Novomeského poezii, kterou analyzoval ze strukturalistického hlediska, ref. 26.

103 Srovnej např. články Branislava Chomy, Ondreje Klokoče, Břetislava Truhláře In Pravda, 1951, roč. 32, č. 65, s. 11; č. 67, s. 5; Kultúrny život, 1951, roč. 6, č. 20, s. 5.

104 Buržoázni nacionalisti - úhlavní nepriatelia slovenskej mládeže. In Pravda, 1951, roč. 32, č. 123, s. 10; Buržoáznonacionalistická zrada na výchove. In Nové slovo, 1951, roč. 8, č. 15, s. 283-284; K ideologickým a pedagogickým otázkam vysokých škôl. In Nové slovo, 1951, roč. 21, s. 407-408; Buržoázni nacionalisti - nepriatelia rozvoja mad’arského a ukrajinského školstva. In Nové slovo, 1951, roč. 31, s. 612-613.

105 Zdrojem kritiky se staly zvláště pověřencovy publikace Dva roky slobodnej školy (1947) a Výchova socialistického pokolenia (1949). 
důkladnou očistu středních a vysokých škol, aby na nich převažovali studenti s dělnickým původem. Mařil rozvoj mad’arského a ukrajinského menšinového školství atd. ${ }^{106}$ Pronesená kritika naprosto demagogicky manipulovala $\mathrm{s}$ fakty. Zcela pomíjela skutečnost, že většinu stanovisek ke školské problematice Novomeský pronesl ve zcela jiném kontextu, tedy ještě před únorem 1948, kdy musel zohledňovat také názory nekomunistických stran a kdy i samotná KSS zastávala $\mathrm{v}$ této oblasti tolerantnější postoje. ${ }^{107}$

Opakovaným atakům byla vystavena také básníkova činnost v komunistické rezistenci a ve Slovenském národním povstání. Jejich vyznění předurčil nechvalně proslulý článek předsedy Sboru pověřenců Karola Bacílka. ${ }^{108}$ Ten obvinil Husáka a Novomeského z toho, že se až do roku 1943 vyhýbali odbojové práci, vedli pohodlný život, unikali represím lud'áckého režimu a pravidelně se stýkali s A. Machem, jemuž reálně sloužili. Po vzniku V. ilegálního vedení KSS zneužili K. Šmidkeho pro své nekalé politické cíle. Bojkotovali strategické směrnice moskevského vedení KSČ a podřizovali stranu nacionalistické buržoazii spolupracující s londýnskou emigrací. Po domluvě s Machem bránili rozšiřování podzemních letáků a partajního tisku. Záměrně sabotovali ozbrojené přípravy protifašistického zápasu. Jeho termín oddalovali, usilovali o minimalizaci bojových operací partyzánů a orientovali se na reakční důstojníky slovenské ar-

106 Odmítavý postoj k mad’arským školám v letech 1945-1948 nevznikl z básníkova popudu. Vyplýval z poválečné strategie celostátní politiky, která nepočítala s existencí neslovanských národnostních menšin v Československu a s níž se ztotožnili i komunisté. Novomeský jako pověřenec školství sice na veřejnosti vystupoval v duchu oficiální linie, vnitřně si však od některých jejích kroků udržoval odstup. Úplnou likvidaci mad’arského školství, k níž došlo bezprostředně po válce, vnímal jako nehumánní akt. Roku 1945 se několikrát přimlouval za to, aby mad’arským dětem bylo až do vyřešení mad’arské otázky (za nějž i on sám považoval jen odsun nebo výměnu obyvatelstva) aspoň na základních školách umožněno vzdělání v mateřském jazyce. A neuspěl. Poté, co se mezi léty 1948-1949 přístup státu k mad’arské komunitě změnil, podporoval opětovné zakládání menšinových škol. KISS, Jozef. Zástoj Ladislava Novomeského v slovensko-mad'arských vzt'ahoch. In PEKNÍK - PETROVIČOVÁ, Laco Novomeský, ref. 58, s. 126-145; širší kontext viz ŠUTAJ, Štefan. Mad'arská menšina na Slovensku po roku 1945. Košice: Univerzita Pavla Jozefa Šafárika, 2015, s. 18-19, 121-122. ISBN 9788081522697.

107 Útoky z jara 1951 měly racionální jádro pouze tehdy, když Novomeskému v čele pověřenectva vyčítaly nedostatečnou radikálnost. Básník se po roce 1945 opravdu snažil jednat uvážlivě a v mezích možností i tolerantně. Měl nechut' k razantním krokům, které mohly způsobit více škody než užitku. Proto si např. na pověřenectvu v roce 1945 ponechal část původního úřednického aparátu, jelikož jiný reálně neměl k dispozici. Ze stejného důvodu odmítal po osvobození rozsáhlou čistku v řadách učitelstva, nebot' kvalifikované odborníky neměl kdo nahradit atd. Národní archiv, f. KSČ-ÚV (1945-1989), 03/10 (barnabitská komise), sv. 3, a. j. 40, beseda se s. L. Novomeským, 5. 9. 1963, s. 22.

108 Buržoázni nacionalisti v čase ilegality a v prípravách Slovenského národného povstania. In Pravda, 1951, roč. 32, č. 83, s. 5. 
mády. S jejich pomocí chtěli povstaleckou akci uskutečnit ve formě vojenského převratu, který by z bojů vyloučil lidové vrstvy a zachoval na Slovensku i po válce panství buržoazie. Povstání tak de facto zradili. ${ }^{109}$ Bacílkova tvrzení posléze do detailu posloužila stranickým funkcionářům i vyšetřovatelům StB při konstrukci obžaloby proti tzv. slovenským buržoazním nacionalistům. ${ }^{110}$ Zároveň přispěla ke zrodu zcela deformované interpretace dějin SNP, která až do počátku šedesátých let ovládla veřejný diskurz a stala se závaznou výkladovou normou pro stranickou propagandu i historiografii. ${ }^{111}$ Povstání, jež po válce bylo silným zdrojem sebevědomí slovenských politických elit, sice navenek oslavovala, ale jeho národně politický program, úlohu jednotlivých osobností i konkrétní události překrucovala nebo zamlčovala.

Propagandistická kampaň proti tzv. slovenskému buržoaznímu nacionalismu byla ještě vyhrocována četnými projevy a články stranických funkcionářu a žurnalistů (Široký, Bašt’ovanský, Bacílek, Edo Friš, Samuel Takáč, Štefan Rais, Oto Krajňák, Miloš Marko aj.), které Novomeského až stereotypně napadaly. ${ }^{112}$ Od podzimu 1951 ale její intenzita postupně klesala, nebot' po zatčení Rudolfa Slánského se do popředí dostal ideologický zápas proti sionismu a kosmopolitismu. ${ }^{113}$ Přesto zůstala bezprostřední součástí slovenské reality až do roku 1963 a důsledky její existence se projevovaly i později. Příčin můžeme nalézt hned několik.

Tažení proti buržoazně nacionalistické úchylce dlouhodobě fungovalo jako nástroj centralistické (post)stalinské politiky, který vedení komunistické strany utilitárně využívalo, kdykoliv se cítilo aktuálním děním na Slovensku ohroženo. Výrazně tak poznamenalo slovenský politický život a negativně zasáhlo do poválečného vývoje česko-slovenských vztahů. Přispělo k eliminaci státoprávní rovi-

109 V podobném duchu vystupovali v tisku např. Andrej Sarvaš, Viliam Šalgovič, Mieroslav Hysko aj. Srov. Zradcovská úloha buržoáznych nacionalistov pri plnení vojenských ciel'ov Povstania. In Pravda, 1951, roč. 32, č. 152, s. 5; Boj za mier a socializmus - odkaz národného povstania. In Kultúrny život, 1951, roč. 6, č. 35, s. 1 a 4; Slovenské národné povstanie - vyvrcholenie boja komunistickej strany za slobodu. In Nové slovo, 1951, roč. 8, č. 35, s. 685-689.

110 Bacílek měl k zúčtování s Husákem a Novomeským také osobní motivy, nebot' za války se v odbojové práci neosvědčil a za SNP sehrál jen okrajovou úlohu. Ve vztahu ke komunistickým intelektuálům dlouhodobě trpěl pocitem méněcennosti a záští. Srovnej PEŠEK, ref. 78, s. 24-26; KAPLAN, Karel. Mocní a bezmocní. Toronto: Sixty-Eight Publishers, 1989, s. $312-$ 314. ISBN 0887812090.

111 Viz JABLONICKÝ, Jozef. Glosy o historiografii SNP. Bratislava: NVK International, 1994, s. 29-35. ISBN 8085727196; HUDEK, Adam. Najpolitičtejšia veda. Slovenská historiografia v rokoch 1948 - 1968. Bratislava: Historický ústav SAV, 2010, s. 142-143. ISBN 9788097030230.

112 Srov. zvláště jednotlivá čísla Pravdy a Nového slova z jara a léta 1951.

113 Jeho kontury lze vysledovat kupř. z brožury KOPECKÝ, Václav. Proti kosmopolitismu jako ideologii amerického imperialismu. Praha: Orbis, 1952. 
ny slovenské otázky, která byla v podstatě zúžena jen na problematiku industrializace a ekonomického vyrovnání Slovenska s českými zeměmi. Napomohlo faktické likvidaci posledního zbytku slovenské národně politické reprezentace, který povstalecká garnitura KSS po únoru 1948 ztělesňovala. Ve východní polovině republiky tak definitivně zmizela mocenská síla schopná v rámci společného státu formulovat a prosazovat specifické zájmy a potřeby Slovenska ve sfére politiky, ekonomiky, sociálních záležitostí či kultury nebo dokonce postulovat nějakou svébytnou slovenskou cestu k socialismu. Slovenské národní orgány (SNR, Sbor pověřenců), jež tyto zájmy a potřeby mohly vyjadřovat, disponovaly minimálními kompetencemi a zcela podléhaly pražskému centru. Slovensko definitivně přestalo být spolutvưrcem (subjektem) politiky a stalo se pouhým objektem politické linie, jejíž principy se utváŕely mimo něj, byt' za př́itomnosti určitého počtu funkcionářu slovenské národnosti. Rychlý vzestup direktivního centralismu, jehož četné unifikační tendence byly ve slovenském prostředí mnohdy vnímány jako rezidua prvorepublikového čechoslovakismu, přispíval k nenápadnému, avšak setrvalému zhoršování česko-slovenského poměru. Zesiloval nespokojenost obyvatelstva z neplnoprávného postavení Slovenska v republice, která př́ležitostně získávala nacionálně podbarvený protičeský osten. Její projevy byly vládnoucí mocí systematicky potlačovány s utilitárním odůvodněním, že pozůstatky lud'áctví a tzv. buržoazního nacionalismu zůstávají na Slovensku stále živé. ${ }^{114}$ Nárůst negativních tendencí ve vývoji česko-slovenského soužití, který způsobila kampaň proti tzv. slovenskému buržoaznímu nacionalismu, mohl ale Novomeský zaregistrovat až po svém propuštění z vězení. Nesporně se ho bolestně dotýkal, nebot' již od třicátých let náležel mezi intelektuály, kteří se snažili slovenskou otázku reálně řešit, a téměř celoživotně hledal nejpříhodnější podobu česko-slovenských vztahů.

Kampaň proti tzv. buržoaznímu nacionalismu zároveň tvrdě postihla slovenské intelektuály, zejména jejich levicovou část, svázanou již od první republiky četnými pouty s davisty a spoluvytvářející po roce 1945 linii kulturní politiky KSS. Stala se symptomem nedůvěry v celou inteligenci jako sociální vrstvu. ${ }^{115}$

114 K recidivám boje proti tzv. buržoaznímu nacionalismu ve druhé polovině padesátých let viz PEŠEK, Jan. Slovensko na prelome 50. a 60. rokov. Politicko-mocenské aspekty vývoja. Brno: Prius, 2005, s. 10-16, 33-35. ISBN 8072850598; MARUŠIAK, Juraj. Slovenská literatúra a moc v druhej polovici pätdesiatych rokov. Brno: Prius, 2001, s. 27-28, 47-50, 123n. ISBN 8090299512.

$115 \mathrm{O}$ ostražitosti vedení KSS svědčila slova Štefana Bašt'ovanského z počátku kampaně: „Pravda, čo chceme od našej inteligencie je, aby sa vzdala svojho individualizmu, malomeštiackeho anarchizmu, aby sa vzdala predstavy, že ona má nejaké zvláštne postavenie v národe. My vieme, že vedúcou silou pri budovaní socializmu v národe je robotnícka trieda. A čím skôr a lepšie to naša inteligencia pochopí, [...] tým lepšie bude môct' uplatňovat'svoje sily a slúžit' vlastnému národu. " Buržoázny nacionalizmus - zrada na národných záujmoch. In Nové slo- 
Citelně zastrašila slovenskou duchovní sféru, narušila kontinuitu intelektuálního a kulturního dění, které, zvláště mezi lety 1951-1952, téměř paralyzovala. Zcela překroutila interpretaci činnosti řady protagonisti̊ slovenské politiky a kultury po roce 1918 a mnohdy pošpinila jejich lidský štít. Zploštila vývoj společenských věd (historie, literární věda), protože jakékoliv výraznější akcentování slovenské svébytnosti v předmětu jejich zájmu, respektive pokusy o objektivnější zhodnocení konkrétních jevů, událostí či osob, se mohly stát záminkou k represi. Některé literární tvưrce dotlačila $\mathrm{k}$ autocenzuře a $\mathrm{k}$ otrockému přejímání postulátů socialistického realismu. ${ }^{116}$ Neblahé důsledky toho vývoje byly překonávány jen s obtížemi. ${ }^{117}$ Nemálo slovenských intelektuáli̊, kteří se po XX. sjezdu Komunistické strany Sovětského svazu (KSSS) pokusili poukázat na neudržitelnost konstrukce tzv. buržoazního nacionalismu, zaplatilo za své úsilí mnohostrannou perzekucí. ${ }^{118}$ Motivace jejich jednání měla, nikoliv náhodou, většinou osobní ráz.

Rozpoutané propagandistické běsnění z jara 1951 si totiž vybralo dlouhodobou daň také v morální a psychologické rovině. Slovenským komunistickým intelektuálům, generačním vrstevníkům davistů i př́islušníkům poválečné generace, kteří se na něm $\mathrm{z}$ různých pohnutek podíleli, většinou způsobilo silné vnitřní trauma. Některým v podstatě záhy, jiným teprve s odstupem let, kdy byly

vo, 1951, roč. 8, č. 11, s. 203.

116 Mnozí z nich navíc cenzurovali a upravovali svá starší díla. Srov. PETRÍK, Vladimír. Autocenzúra druhých a d’alších vydaní kníh v pät’desiatych rokoch. In DRUG, ref. 27, s. 126-127.

117 V literární sféře, jejíž protagonisté podlehli po březnovém a květnovém spisovatelském aktivu existenčním obavám a pasivitě, lze vysledovat první nepatrnou oblevu již na přelomu 1951/1952. Po zatčení Slánského a četných personálních změnách ve stranickém aparátu, spojenými s propagandistickým bojem proti tzv. slánštině, došlo k drobné korektuře kulturní politiky KSČ, která byla založena na poněkud umírněnějším uplatňování ideově-estetických kritérií, uváženějším prístupu ke kulturnímu dědictví a vstřícnějším postoji k některým komunistickým umělcům starší generace. Změna oficiální linie se projevila také na Slovensku, kde ze stranických struktur museli odejít funkcionáři, kteří byli spjati s kulturně-politickými kampaněmi předchozího období (Šefránek, Špitzer). Odrazila se pochopitelně i ve spisovatelské organizaci. Na zasedání výboru Slovenské sekce SČSS v prosinci 1951 odsoudil Lajčiak květnový aktiv spisovatelů jako levičácký a sektářský. Z pětice tvůrců (Chorváth, Matuška, Mináč, Tatarka, Bakoš) sňal obvinění z buržoazního nacionalismu, jejich kritiku označil za nespravedlivou a nesprávně spojovanou s kriminálními př́pady „zrádců“ Novomeského a Clementise. Na ostrakizaci davistů se tak nic nezměnilo a Lajčiak zůstal i nadále $\mathrm{v}$ čele spisovatelské organizace. V podobném duchu, aniž by jakkoliv zpochybnil svá odmítavá stanoviska k Novomeskému, přednesl v březnu 1952 svou sebekritiku i Juraj Špitzer. V širších souvislostech viz PETRÍK, ref. 27, s. 83-86; BÍLIK, ref. 27, s. 29-31; DRUG, ref. 27, s. 37-38; DRUG, ref. 46, s. 117-119. K problematice proměny celostátní kulturní politiky v letech 1951-1952 viz KNAPÍK, Jiří. Kulturní politika, jeji systém a aktéři 1948-1956. Praha: Nakladatelství Libri, 2006, s. 112-198. ISBN 807277316.

118 Srov. např. MARUŠIAK, ref. 114, s. 12, 24, 47, 123-124, 130-134; dále PEŠEK, ref. 114, s. $10-12$. 
pozvolna odhalovány zločiny éry stalinismu. Zatížilo jejich svědomí mravním břemenem spoluúčasti, s nímž někteř́ zápasili až do konce života. ${ }^{119}$ Pocit viny ve vztahu k Novomeskému, který byl s mnohými z nich dosud spojen četnými pracovními a přátelskými pouty, hrál $\mathrm{v}$ tomto bolestném zpytování zásadní úlohu. Po básníkově podmínečném propuštění z vězení v prosinci 1955, kdy nesměl publikovat a vrátit se na Slovensko, ${ }^{120}$ se jednotlivci snažili napravit na něm spáchané křivdy různými způsoby. Někteří otevřeným distancováním se od vlastního podílu na kampani proti buržoaznímu nacionalismu a úsilím o rehabilitaci postižených osob, ${ }^{121}$ jiní publikační činností, která se snažila v reálnějších konturách vykreslit zvrácenou povahu éry tzv. kultu osobnosti ${ }^{122}$ či znovuotevřít nedořešenou státoprávní otázku, ${ }^{123}$ další upřímnou snahou pomoci básníkovi při návratu do normálního života a při očistě jeho jména. ${ }^{124}$ Mnozí také Novomeského osobně požádali o odpuštění.

Zastavme se především u sebereflexe tří mužů, jejichž útočné postuláty, pomineme-li ostré výroky jim nadřízených stranických funkcionářů, nejvíce ovlivnily argumentační ráz pogromistického tažení proti Novomeskému. Július Šefránek musel roku 1953 kvůli posunu linie kulturní politiky KSČ i pro svůj židovský původ opustit aparát ÚV KSS. O dekádu později se jako člen expertního

119 LONDÁKOVÁ, ref. 29, s. 479-480.

120 Měl přikázaný trvalý pobyt v Praze, kde do roku 1962 pracoval jako výstavnický referent v Památníku národního písemnictví. Do Bratislavy se odstěhoval až na jaře 1964.

121 V tomto duchu vystoupili během roku 1956 na schůzích KSS či svazu spisovatelů O. Pavlík, E. Friš a C. Štítnický, o sedm let později na novinářském sjezdu M. Hysko. Srov. MARUŠIAK, ref. 114, s. 12, 21, 24, 47, 131; PAVLÍK, ref. 20, s. 38-43; I. zjazd slovenských novinárov v r. 1963. Bratislava: Zväz slovenských novinárov, 1968, s. 53-71.

122 Např́klad Tatarkova satirická novela Démon súhlasu (1956), Mnačkovy Oneskorené reportáže (1963) a román Ako chutí moc (1967), Špitzerova próza Patrím k vám (1964).

123 Auru odvážlivce si mezi nimi načas získal historik M. Gosiorovský, který ve svém memorandu z roku 1963, zaslaném vedení KSČ i KSS, otevřeně napsal, že napětí v česko-slovenských vztazích může být překonáno jedině realizací federativního uspořádání státu. GOSIOROVSKÝ, Miloš. K niektorým otázkam vzt’ahu Čechov a Slovákov v politike Komunistickej strany Československa. In Historický časopis, 1968, roč. 16, č. 3, s. 354-406. K tomu je však nutné dodat, že Gosiorovský, jenž v padesátých letech výrazně přispěl k deformované interpretaci SNP, své názory vždy oportunně přizpůsoboval proměnám politického kurzu KSČ.

124 Toto úsilí lze ilustrovat na pozdějším chování některých členů výboru Slovenské sekce SČSS, kteří v březnu 1951 hlasovali pro vyloučení svého kolegy ze spisovatelské organizace i z literatury. Kupř́íkladu Pavol Horov Novomeského podporoval při neúspěšném pátrání po jeho ztracené vězeňské poezii, zároveň mu v době, kdy nesměl publikovat, existenčně pomohl nabídkou překladů prozaických děl. Ján Ferenčík s básníkem spolupracoval na jeho převodu poezie Borise Pasternaka. Ivan Kusý vyvinul na počátku šedesátých let značné úsilí, aby se Novomeský mohl přestěhovat do Bratislavy a pracovat v Ústavu slovenské literatury SAV. Karol Rosenbaum později editoval několik svazků Novomeského publicistiky, Ján Brezina vydal rozsáhlou monografii o básníkově poezii atd. 
týmu barnabitské komise podílel na odmítnutí tezí o existenci tzv. buržoazního nacionalismu na Slovensku. V souvislosti s rehabilitací politického programu SNP básníka přepjatě adoroval. ${ }^{125}$ Doklady, že by se jakkoliv vracel ke svému vystoupení na spisovatelském aktivu, však zatím nemáme.

O nesnadnosti vyrovnání se s vlastní minulostí naopak dosti vypovídá chování J. Špitzera. Ještě v roce 1955 publikoval monografii o Jilemnickém, kde poněkud mírnějším slovníkem zopakoval téměř všechna obvinění, která na adresu Novomeského v letech 1950-1951 vyřkl. ${ }^{126}$ Po XX. sjezdu KSSS rychle pochopil svůj omyl. V atmosfére počínající destalinizace se jako šéfredaktor Kultúrneho života (1956-1957) stal trvalým stoupencem liberalizace komunistického režimu a usiloval o objektivní přehodnocení vývoje meziválečné slovenské literatury. Za svůj podíl na mocenských čistkách se styděl až do konce svého života, neváhal o něm otevřeně hovořit a nabízel pomocnou ruku obětem represí padesátých let. Svou vinu se snažil odčinit i ve vztahu k Novomeskému. Navštěvoval ho v jeho pražském vyhnanství, lidsky se s ním sblížil a vícekrát se mu za své selhání soukromě omluvil. ${ }^{127}$ Po zvolení za tajemníka Svazu československých spisovatelů (leden 1960) soustavně usiloval o básníkovu politickou rehabilitaci, četl v rukopise jeho nové básně a vyvíjel značné úsilí, aby mu bylo opět povoleno publikovat poezii. Posléze pomáhal zprostředkovat Novomeského přijetí do

125 Ve své vzpomínce na povstaleckou Pravdu o svém bývalém redakčním kolegovi napsal: „Laco Novomeský bol dosial' najväčším slovenským komunistickým novinárom a hádam najväčsím slovenským novinárom vôbec a myslím si, že to bude vel'ké štastie pre našu žurnalistiku, ked' nám znovu vyrastie novinár tohto formátu, tej myslitel'skej úrovne, toho vznešeného štýlu a toho estetického vzt'ahu básnika k úprave tlače, aký mal Laco Novomeský. " ŠEFRÁNEK, Július. Niekol'ko poznámok o povstaleckej Pravde. In Novinářský sborník, 1964, roč. 9, č. 2, s. 211.

126 ŠPITZER, Juraj. Peter Jilemnický. Bratislava: Vydavatel'stvo SAV, 1955, s. 36, 52-56, 61-66, 163-168, 171-173, 219-220, 233-240, 287.

127 O tom, že návraty k počátku padesátých let byly pro Špitzera mimořádně traumatizující, svědčí jeho kajícná gratulace k Novomeského šedesátinám z prosince 1964. Napsal v ní: „, Od nášho prvého stretnutia po Tvojom návrate Stamodtial bolo pre mňa každé stretnutie s Tebou, Tvojimi veršami bolestne vzrušujúce, pritažlivé a očistné. [...] V predstave, že bojujem za akúsi vyššiu stranícku pravdu, ubližil som Ti, s plným zaujatím som prijal tézy o zhubnej činnosti DAVu a jeho jednotlivých predstavitel'och, vedecky som doložil konštrukciu, ktorá bola falošná, podl'ahol som i ja masovej psychóze, ktorá sa začala na onom pamätnom zasadnutí Ústredného výboru komunistickej strany v apríli 1950 a rozšírila sa ako amok do celej strany. [...] Cítim sa jedným zo zodpovedných, i ked'som nehral prvé husle, ale iba jedného z neskoršich miništrantov. Čo sa stalo, stalo sa, nech história podl'a spravodlivosti urči moje miesto $v$ hereckom komparze tohto strašidelného divadla. [...] Ty vieš, [...] že celá dráma okolo DAVu pôjde so mnou až po hrob, možno je to napriek negativam aj dobre, lebo ostáva ako mravný regulatív, ako vážne memento. [...] Možno sa mi raz podarí ukázat' jeho funkciu pre ,vzostup a pád 'jedného rozumu; ako všetky peripetie spojené so smutne preslávenou kampaňou určili moje zmýšlanie a životné postoje. " Literárny archív Slovenskej národnej knižnice (dále LA SNK), f. Juraj Špitzer, dopis J. Špitzera L. Novomeskému, 22. 12. 1964. 
Ústavu slovenské literatury SAV. ${ }^{128}$ Na druhou stranu však Špitzer v šedesátých letech své názory z roku 1951 veřejně neodvolal, ${ }^{129}$ třebaže o tomto kroku uvažoval a byl k němu prostřednictvím dopisu vybízen i samotným Novomeským: „S atmosférou, zacielením, s omylmi, chybami, s celým tým zvráteným idiotizmom [...] pät'desiatych rokov [treba] sa vyrovnat'. Nazdávam sa, že predovšetkým Ty by si bol najpovolanejši byt'v tej veci iniciatívny. Nie preto, že si bol vtedy silne angažovaný, ale preto, lebo poznáš súvislosti a dosah vecí, skrátka pre svoje dnešné kvality. [...] A tak som si myslel, či by nemal Juraj Špitzer napisat'štúdiu o slovenskej literárnej vede v rokoch pät'desiatych, kde by kriticky rozobral i svoju účast'v nej a tú čiastočnú záležitost', ktorá ho tak vel'mi tiesni? [...] Ty a celá Tvoja generácia, ktorá dnes nesie váhu myslenia a kultúrnej atd'. politiky u nás, je vo vel'kom nebezpečí, ak chce len tak odbehnut tie staré sračky z pätdesiatych rokov a neurobi to, čo spravi každý pes, t. j. ich zahrabe za sebou. Nepripust' a nepripúst'ajte, aby nastupujúca mladšia vlna kritikov, ideológov a teoretikov bola nútená toto zhodnocovanie za Vás zrobit'. Alebo celkom za Vás! "130 Špitzer takovouto studii nikdy nenapsal, ačkoliv se o to vícekrát pokoušel.

Na sklonku Novotného éry své pokání otevřeně formuloval J. Rozner. Zamyšlení nad vlastním konáním z jara 1951 spojil s obecnější úvahou nad mentalitou, morálkou a jednáním slovenských intelektuálů, kteří byli tehdy vystaveni silnému manipulativnímu tlaku. Podobně jako Špitzer připomínal, že se na tažení proti tzv. buržoaznímu nacionalismu podílel víceméně dobrovolně a na základě vlastního úsudku: „Roku 1951 jsem byl predevším přesvědčen, že účast na této kampani - je pro mne - tehdy redaktora politického deniku - povinností v zájmu společnosti, jejiho dalšiho ozdraveni a pokroku. A tím bylo všechno ostatní pro mne vyřešeno. Z hlediska roku 1951. Z dnešního hlediska je možné - a je to třeba - tento tehdejši postoj včetně činu, které z něho vyplývaly, kvalifiko-

128 Ke Špitzerovu názorovému vývoji a aktivitám ŠPITZER, ref. 78, s. 9-15; PEŠEK, ref. 78, s. 331-332; MARUŠIAK, ref. 114, s. 12, 23, 25-36, 42-44; DRUG, Štefan (ed.). Umenie politiky, politika umenia, sv. III. Bratislava: Tatran, 1990, s. 304-309, s. 449-452. ISBN 802200160; PETRÍK, Hl'adanie, ref. 94, s. 98-99; PILǍ̌, Jan. Sluneční hodiny. Praha: Československý spisovatel, 1989, s. 333. ISBN 8022000916.

129 Vladimír Petrík vzpomínal na debaty v Ústavu slovenské literatury SAV: ,,Ked' som mu o tom hovoril, vždy sa nahneval a kategoricky vyhlásil: ,Napiš ty!' Ked' som však o tom [roku 1970] napísal (v rámci spomenutej štúdie o literatúre pät'desiatych rokov), hneval sa. " PETRÍK, Hladanie, ref. 94, s. 99.

130 LA SNK, f. Juraj Špitzer, dopis L. Novomeského J. Špitzerovi 2. 6. 1963. Špitzer básníkovi odpověděl, že souhlasí s jeho pobídkou, ale zároveň není ochoten skládat účty před oportunisty z řad politiků a spisovatelů, kteří počátkem padesátých let ,,skrývali svoje názory, hoci mohli, čo aj v súkromných rozhovoroch, ovplyvnit naše, ak vedeli, že sa robí zlá vec, a teraz vystupujú ako dodatočni mudrci “. LA SNK, f. Juraj Špitzer, dopis J. Špitzera L. Novomeskému, bez data (červen 1963). 
vat jako nezodpovědný, nesvědomitý, a tedy nemorální. [...] Jen bych snad jako doložku ještě pripojil, že to samozřejmě plati o všech podobných vystoupenich $v$ podobných kampanich, v nichž intelektuálové satanizovali údajné nepřátele, dělali nezákonnosti (nemajice tušení, že jsou to nezákonnosti) stravitelnými pro širši veřejnost a takto kypřili půdu pro neomezené manipulováni s lidmi, celou společností a pravdou. Každý, kdo hrál přidělenou úlohu nevědomého, ale tím víc se rozkřikujicího statisty, poslušného neznámých režisérů a ochotně se vžívajicího a vcitujicího do historického scénáře, se pred budoucností poskvrnil a potřísnil nesmazatelnými skvrnami. "131

Z výše napsaných řádek je zjevné, že následky propagandistického zápasu proti tzv. buržoaznímu nacionalismu poznamenávaly ovzduší slovenského intelektuálního života ještě dlouho poté, co byla tato smyšlená konstrukce v roce 1963 odvolána.

Vrat’me se na závěr ještě jednou stručnou poznámkou k Novomeskému. Básník nebyl bezprostředním svědkem diskreditační kampaně, která proti němu byla na jaře 1951 rozpoutána. S razancí, šíří a absurdností útokủ, jimž čelil od svých dosavadních politických spolubojovníků, literárních kolegů a prátel, byl plně konfrontován až po svém návratu ze žaláře. Toto nevědomí mu ale jen stěží mohlo být útěchou, nebot' sám od února 1951 prožíval v Kolodějích a v Ruzyni anabázi mnohem hrůznějšś: kdy všechno, co bylo „venku“ proneseno, co brutálně převracelo jeho myšlenky a skutky naruby, měl vyšetřovatelům StB kajícně doznat a poté přijmout za jediný a opravdový obraz vlastního života, nad kterým byl na jaře 1954 vynesen rozsudek v rámci procesu s tzv. slovenskými buržoazními nacionalisty. Ale okolnosti Novomeského „doznání“ a odsouzení již přesahují rámec této studie.

* Tato studie je dílčím výstupem standardního projektu Grantové agentury České republiky Ladislav Novomeský mezi stalinismem a reformním komunismem: Básník v politice a verejném životě (1945-1970), registrační č́slo P410/16-02046S.

\section{LADISLAV NOVOMESKÝ UND SLOWAKISCHE KULTURELLE GEMEINDE IN DER PROPAGANDISTISCHEN KAMPAGNE GEGEN \\ SOG. BÜRGERLICHEN NATIONALISMUS IM FRÜHLING 1951}

\section{ZDENĚK D O S K O Č IL}

Im Frühling 1950 wurde der Dichter und der Beauftragte für Schulwesens Ladislav Novomeský zusammen mit anderen Vertretern des sogenannten aufständischen Flügels

131 ROZNER, Ján. Davisté a jejich doba. Praha: Československý spisovatel, 1966, s. 156-157. 
der Kommunistischen Partei der Slowakei (Vladimir Clementis, Gustáv Husák, Karol Šmidke) zu Unrecht des sog. slowakischen bürgerlichen Nationalismus zielgerichtet beschuldigt. Die Beschuldigungen der ideologischen Abweichung wurden anschließend unter dem Einfluss der sowjetischen Berater in der Staatssicherheit zur Straftat neuklassifiziert und Novomeský endete im Februar 1951 zusammen mit anderen Funktionären im Gefängnis. Nach ihrer Verhaftung wurde gegen den sogenannten bürgerlichen Nationalismus eine Propagandakampagne ausgelöst, die die Führung der Kommunistischen Partei mit Säuberungen in den Reihen der slowakischen Intelligenz verknüpfte. Novomeský wurde zu einem ihrer führenden Opfer. Auf Veranlassung der Spitzenpolitiker und Arbeiter des Parteiapparates (Julius Šefránek, Juraj Špitzer), die zuvor den ideologischen Ton definiert haben, banden sich die kommunistischen Intellektuellen in die Kampagne im Frühjahr 1951 freiwillig oder unter Zwang ein. Am meisten engagierten sich die Schriftsteller und Journalisten. Ihre in den Medien veröffentlichten Reden und Artikel verurteilten scharf die Poesie und literarische Ansichten von Novomeský, seine Widerstandsarbeit und Aktivitäten im Bildungs- und Kulturbereich. Die Kampagne vom Frühjahr 1951 hat die tschechisch-slowakischen Beziehungen auf lange Jahre beeinträchtigt und negativ in die Entwicklung des slowakischen politischen und kulturellen Bereichs eingegriffen. Bei vielen Intellektuellen, die daran teilnahmen, bewirkte sie ein moralisches Trauma, mit dem sie sich nur schwer auseinandersetzten. Sie beeinträchtigte spürbar auch das Leben von Novomeský, denn die Verurteilungen waren später die Grundlage zur Anklage im Verfahren mit sog. slowakischen bürgerlichen Nationalisten in 1954.

PhDr. Zdeněk Doskočil, Ph.D.

Historický ústav AV ČR, v. v. i.,

Prosecká 809/76, 19000

Praha 9

Česká republika

doskocil@hiu.cas.cz 